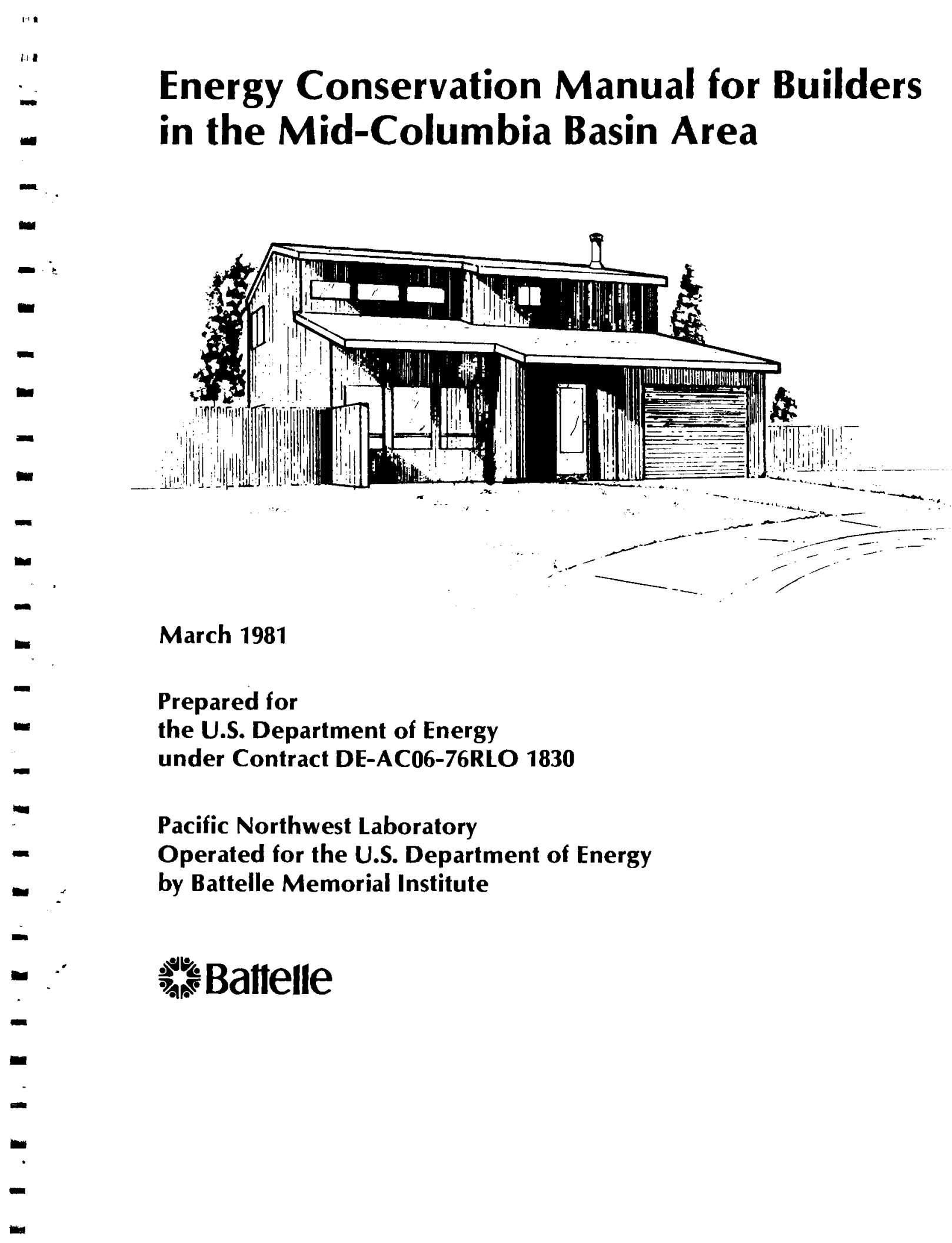


NOTICE

This report was prepared an an account of work sponsored by the United States Government. Neither the United States :nor the Department of Energy, nor any of their employees, nor any of their contractors, subcontractors, or their employees, makes any warranty, express or implied, or assumes any legal liability or responsibility for the accuracy, completeness or usefulness of any information, apparatus, product or process disclosed, or represents that its use would not infringe privately owned rights. This report does not reflect official views or policy of the above-mentione: 1 . institutions. Mention of trade names or commercial products does not constitute endorsement or recommendation for use.

The views, opinions and conclusions contained in this report are those of the contractor and do not necessarils - represent those of the United States Government or the United States Departnient of Energy.

PACIFIC NORTHWEST LABORATORY

operated by

BATTELLE

for the

UNITED STATES DEPARTMENT OF ENERGY

under Contract DE-AC06-76RLO 1830

Printed in the United States of America

Availabie from

Naticnal Technical Information Service

United States Department of Commerce

5285 Port Royal Road

Springtield. Virginia 22151

Price: Printed Copy 5

*; Microfiche $\$ 3.00$

NTIS

-Pages Selling Price

$001-025$

$026-050 \quad \$ 4.50$

051-075 \$5.25

$076-100 \quad \$ 6.00$

$101-125 \quad \$ 6.50$

$126-150 \quad \$ 7.25$

$151-175 \quad \$ 8.00$

176-200 $\$ 9.00$

201-225 \$5.25

226-250 \$9.50

251-275 \$10.75

$276-300 \quad \$ 11.00$ 
PNL-3607

UC-95d

\section{Energy Conservation Manual for Builders in the Mid- Columbia Basin Area}

R. P. Mazzucchi

L. A. Nieves

W. J. Hopp

March 1981

Prepared for the

U.S. Department of Energy

under Contract DE-AC06-76RLO 1830

Pacific Northwest Laboratory

Richland, Washington 99352 


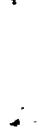

$\because$

• 


\section{Contents}

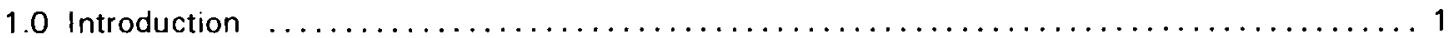

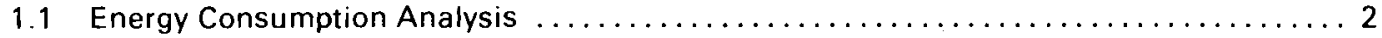

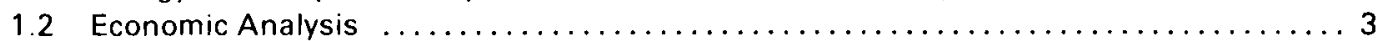

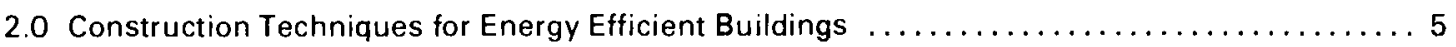

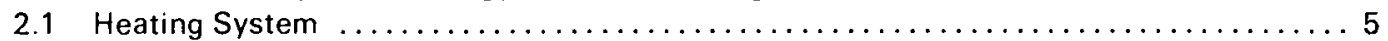

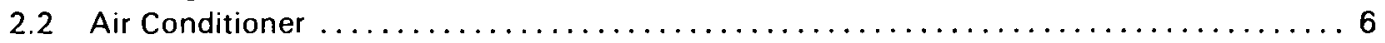

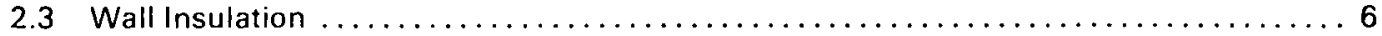

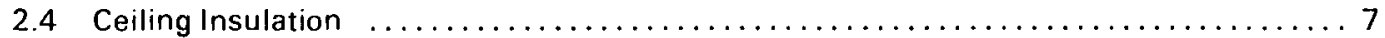

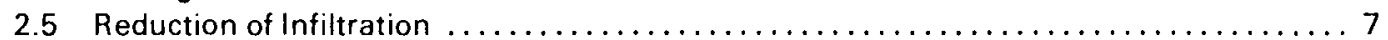

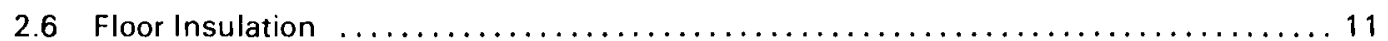

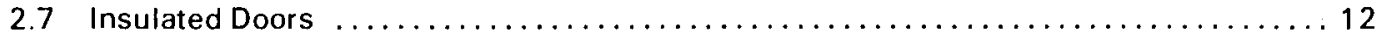

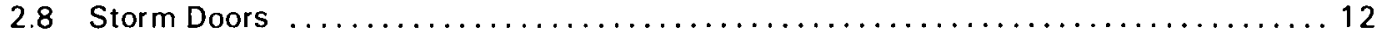

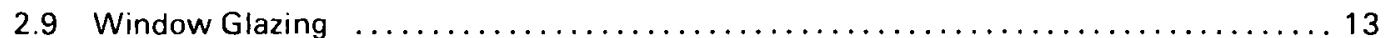

2.10 Operable Windows $\ldots \ldots \ldots \ldots \ldots \ldots \ldots \ldots \ldots \ldots \ldots \ldots \ldots \ldots \ldots \ldots \ldots \ldots \ldots \ldots \ldots \ldots \ldots, 13$

2.11 Window Framing $\ldots \ldots \ldots \ldots \ldots \ldots \ldots \ldots \ldots \ldots \ldots \ldots \ldots \ldots \ldots \ldots \ldots \ldots \ldots \ldots \ldots, 14$

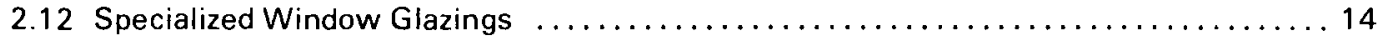

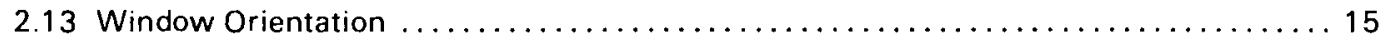

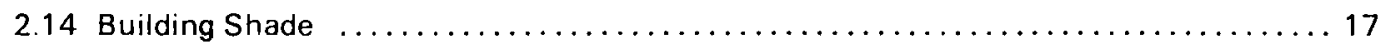

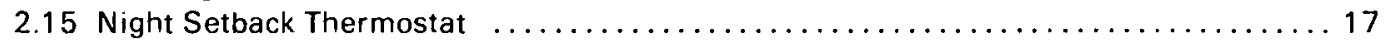

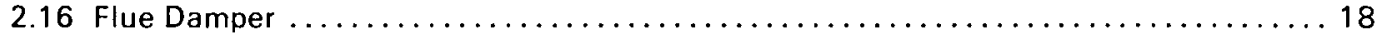

2.17 Wood Stoves/Fireplaces ......................................... 18

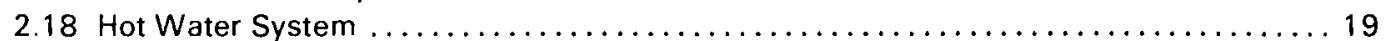

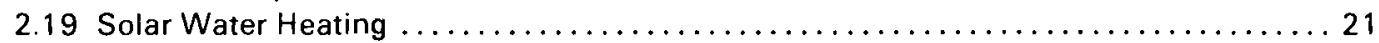

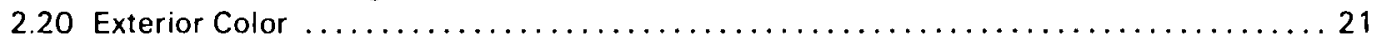

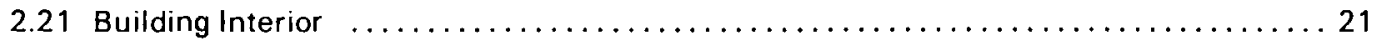

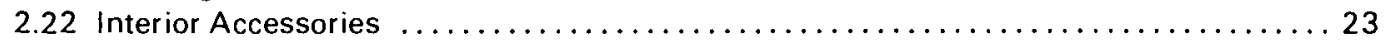

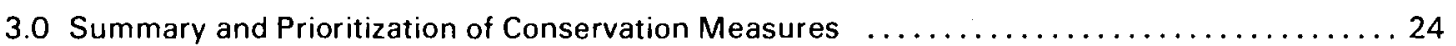

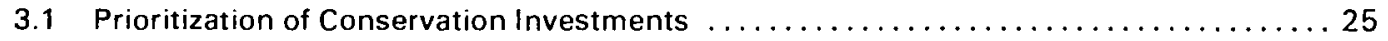

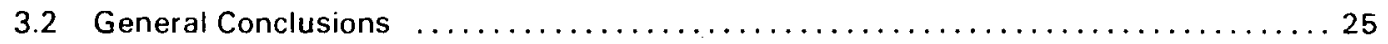

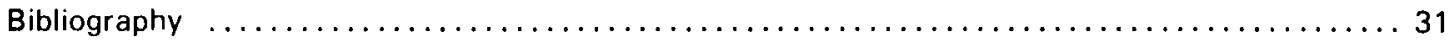

Appendix A

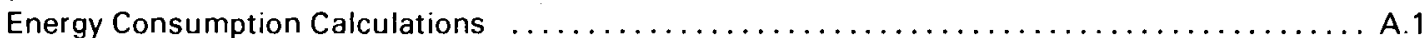

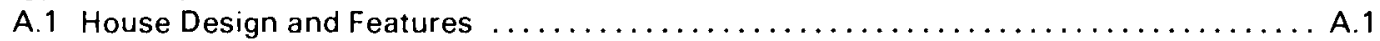

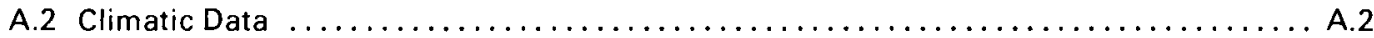

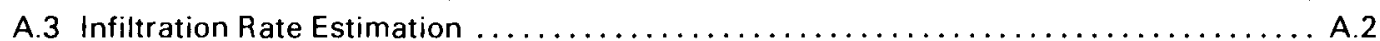

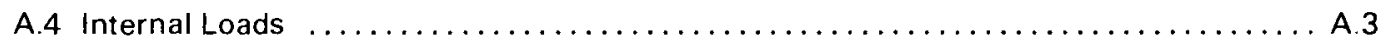

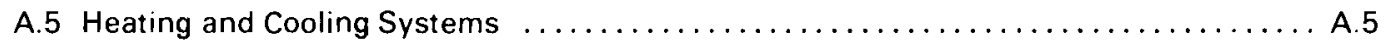

Appendix B

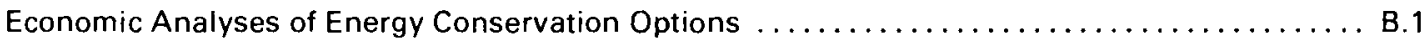

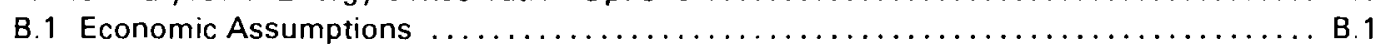

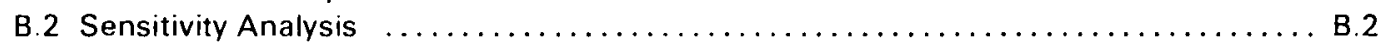

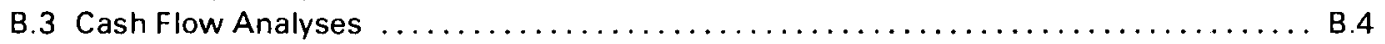


B.3.1. Analysis for Option of Increasing Wall Insulation From R-11 to R-19 ..... B.4

B.3.2 Analysis for Option of Increasing Wall Insulation from R-19 to R-27 ....... B.5

B.3.3 Analysis for Option of Increasing Ceiling Insulation

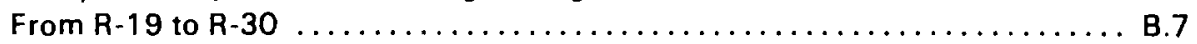

B.3.4 Analysis for Option of Increasing Ceiling Insulation From R-30 to R-38 .... B.8

B.3.5 Analysis for Option of Replacing Double Glazing with Triple Glazing ........ B.9

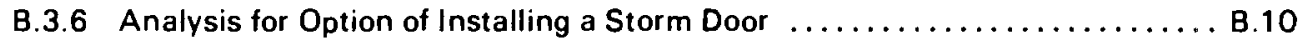

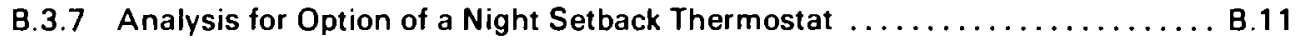

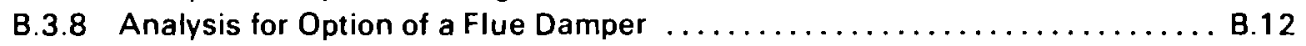

References $\ldots \ldots \ldots \ldots \ldots \ldots \ldots \ldots \ldots \ldots \ldots \ldots \ldots \ldots \ldots \ldots \ldots \ldots \ldots \ldots \ldots \ldots$

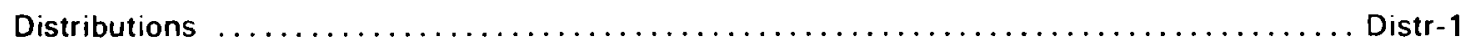




\section{Figures}

No.

1 Area of Direct Applicability of Findings $\ldots \ldots \ldots \ldots \ldots \ldots \ldots \ldots \ldots \ldots \ldots \ldots \ldots \ldots \ldots, 3$

2 Air Leakage Spots in Conventional Construction $\ldots \ldots \ldots \ldots \ldots \ldots \ldots \ldots \ldots \ldots \ldots \ldots$

3 Use of Vapor Barrier Pans $\ldots \ldots \ldots \ldots \ldots \ldots \ldots \ldots \ldots \ldots \ldots \ldots \ldots \ldots \ldots \ldots \ldots \ldots, \quad 9$

$4 \quad$ Vapor Barrier Details Cross-Section View $\ldots \ldots \ldots \ldots \ldots \ldots \ldots \ldots \ldots \ldots \ldots \ldots \ldots, 10$

5 Vapor Barrier Installation for Partition Wall (Cross-Section View) $\ldots \ldots \ldots \ldots \ldots \ldots \ldots . . \ldots$

$6 \quad$ Vapor Barrier Installation at Window (Section View Looking Down) $\ldots \ldots \ldots \ldots \ldots \ldots, 11$

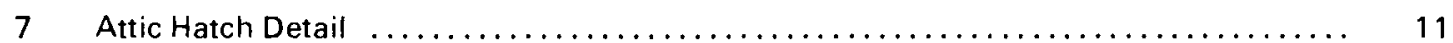

8 Heat Flow Through Double Glazing Compared to R-19 Stud Wall $\ldots \ldots \ldots \ldots \ldots \ldots . . \ldots$

… 9 Heat Flow Through Triple Glazing Compared to R-19 Stud Wall ................ 16

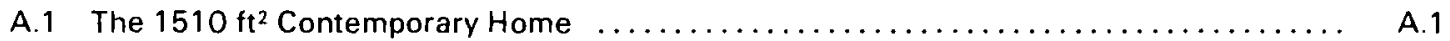




\section{Tables}

No.

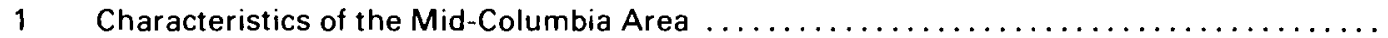

2 Effects of Increasing Wall Insulation Levels $\ldots \ldots \ldots \ldots \ldots \ldots \ldots \ldots \ldots \ldots \ldots \ldots \ldots \ldots \ldots \ldots$

3 Effects of Increasing Ceiling Insulation Above $R-19 \ldots \ldots \ldots \ldots \ldots \ldots \ldots \ldots \ldots \ldots$

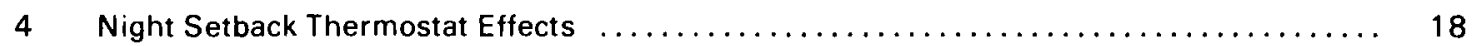

5 Cost Equivalents for Wood, Electric Furnace or Gas Heating $\ldots \ldots \ldots \ldots \ldots \ldots \ldots \ldots$

6 Hot Water System Energy Conservation Options ........................... 20

7 Area of Concrete in $\mathrm{Ft}^{2}$ Required to Store Solar

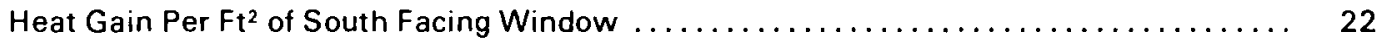

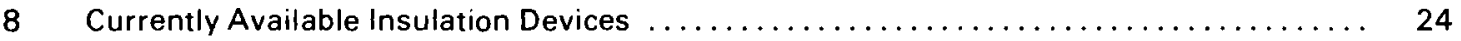

9 Economic Analysis of Conservation Measures for a Home with an Electric Furnace and Electric Air Conditioning $\ldots \ldots \ldots \ldots \ldots \ldots \ldots \ldots \ldots \ldots \ldots \ldots$

10 Economic Analysis of Conservation Measures for a Home with

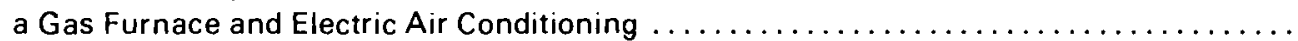

11 Economic Analysis of Conservation Measures for a Home with a Heat Pump

12 Costs for the Prototype House with Various Conditioning Systems Conservation Packages

A. 1 Estimated Average Internal Loads

A.2 Internal Load Schedule for Prototype House

B.1 The Annual Savings from Installing a Storm Door in a Natural Gas-Heated House (in constant 1980 dollars) 


\section{Energy Conservation Manual for Builders in the Mid-Columbia Basin Area}

\subsection{Introduction}

Consumer demand for energy-efficient homes has mounted dramatically in recent years, primarily in response to increasing fuel costs for building space conditioning. To satisfy home buyers' and builders' need for information on ways to reduce energy consumption in new homes, the Department of Energy (DOE) has funded energy conservation research and development efforts. This handbook presents the results of a comprehensive costeffectiveness evaluation of energy conservation measures currently available for use in typical residential buildings.

Residential buildings accounted for approximately $15 \%$ of the total energy consumption in the United States last year. Because more than $60 \%$ of residential energy use provides space conditioning and $15 \%$ furnishes water heating, energy-efficient construction of homes can

- $\quad$ significantly reduce the total demand for energy. Energy efficiency not only benefits home buyers directly through reduced fuel bills, but also indirectly through reduced demand for new energy supplies. Thus, efficiency may decrease future energy costs, adverse environmental impacts, reliance on insecure energy imports, the trade deficit, and inflationary pressures. Although reduced residential energy use will not solve all of our national energy problems, it is clearly a movement in the right direction.

The potential value of incorporating energy-conserving features in Mid-Columbia Region homes is significant even though most energy prices in the Northwest are substantially lower than the national average. Through attention to utilization of passive solar techniques, quality of construction, and selection of appropriate building materials, space conditioning energy requirements may be reduced with little or no additional construction cost. The addition of features with a breakeven period of 5 years or less can reduce heating and cooling energy use by $44 \%$ and cost less than $\$ 600.00$ in 1980 . Analyses have indicated that the use of currently available conservation strategies can dramatically reduce the energy consumption of new buildings.

-- Section 2 of this report discusses construction techniques for energy-efficient buildings and - presents estimates of the cost of incorporating the conservation measures in the prototype building, the resultant annual energy savings, and the value of that annual energy savings based upon typical regional fuel prices. In Section 3 this information is summarized to - prioritize conservation investments according to their economic effectiveness and offer general recommendations to home builders. Appendix A contains detailed information pertaining to the energy consumption calculations. Appendix $B$ presents the methodology, assumptions, and results of a detailed cash flow analysis of each of the conservation items for which sufficient performance and cost data are currently available. 


\subsection{Energy Consumption Analysis}

Investigations of energy use in building have been receiving increasing support and attention from both the government and industry. Sophisticated computer techniques that simulate the response of entire buildings to hourly changes in numerous climatic parameters and estimate energy requirements of the conditioning systems are now available. Combining the results of computer simulations with actual building performance data facilitates a reliable, inexpensive, and rapid estimate of the energy savings potential of various conservation measures.

The powerful DOE 2.0A computer program provided estimates of the energy use of typical new residences with various conservation options by simulating the performance of the buildings for each hour of a typical meteorological year. The program has been validated with actual building performance and found to yield estimates with $\pm 10 \%$ accuracy. Information on the prototype building selected for detailed analysis and the computation of energy savings is provided in Appendix A.

For a few items, namely flue dampers, wood stoves, hot water conservation, and heat pumps, energy performance has been estimated without the benefit of the computer program due to program limitations. Because all evaluations have been tailored to climatic conditions in the Mid-Columbia Basin area, as summarized in Table 1, the direct applicability of the findings is probably limited to areas lying within about 50 miles of the climate monitoring station located on the Hanford Reservation. This region is depicted in Figure 1.

Table 1. Characteristics of the Mid-Columbia Area

\begin{tabular}{|c|c|}
\hline CLIMATE & \\
\hline Heating Degree days (65 Base) & 5300 \\
\hline Cooling Degree days $\left(65^{\circ}\right.$ Base $)$ & 1000 \\
\hline$\%$ of Possible Sunshine & $59 \%$ \\
\hline Annual Rainfall & $5 \mathrm{in.}$ \\
\hline Annual Snowfall & $7 \mathrm{in.}$ \\
\hline Average Wind Speed & $7 \mathrm{mph}$ \\
\hline 1980 Energy Costs & Average \\
\hline Electricity ( $\mathrm{c} / \mathrm{kWh}$ ) range: 1.1 to 3.4 & 1.54 \\
\hline Natural Gas $(\mathrm{c} /$ therm) range: 50 to 60 & 55.0 \\
\hline
\end{tabular}




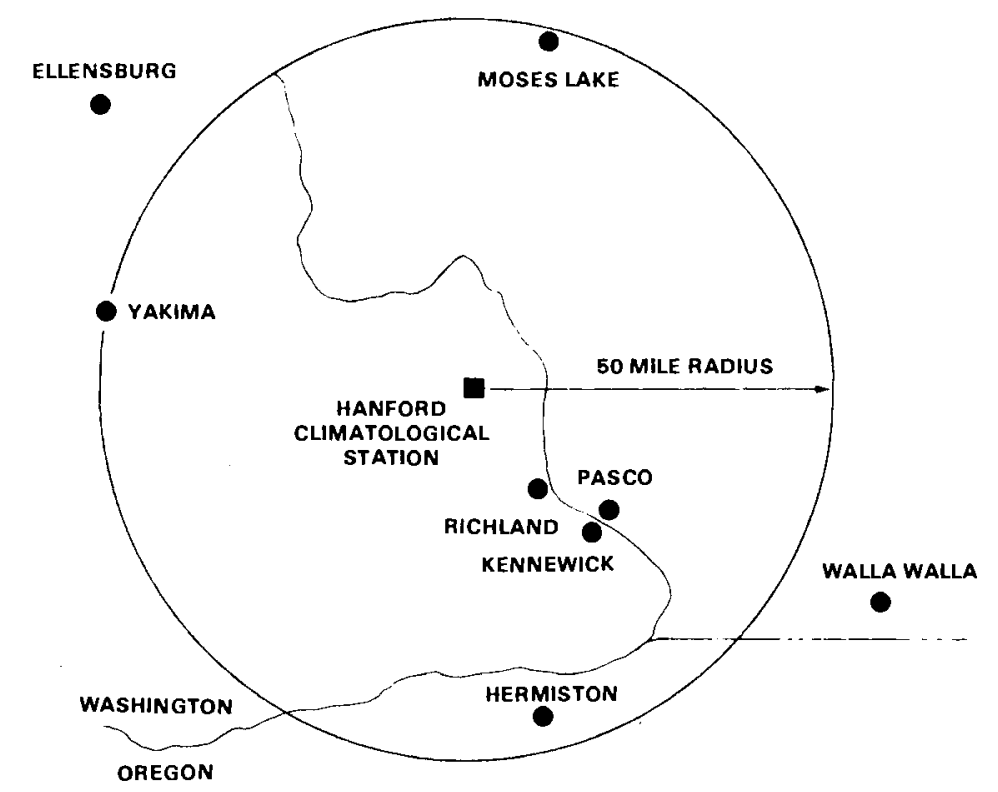

Figure 1. Area of Direct Applicability of Findings

\subsection{Economic Analysis}

The conservation measures examined in this report have been analyzed to provide estimates of their probable cost and benefit to the typical homebuyer. The costs of the measures have been provided by local equipment suppliers and building contractors with extensive residential development experience. Using fuel prices appropriate for the region, the benefits, namely dollar savings on energy bills, have been calculated by heating system type.

The estimated incremental costs of incorporating the conservation measures in new homes include material and installation costs as well as a builder overhead expense of $25 \%$. To the extent possible they are based upon actual job costs as reported by local builders. In calculating the incremental costs of some items, night set-back thermostats for example, the cost of a conventional item is credited against the conservation item cost to yield a true incremental cost. For a few items, such as location of windows, there is no dollar cost, although window placement may affect the salability of the building. The cost estimates do not consider the - effect of energy efficiency on the resale value of the home.

The dollar savings from fuel bill reductions attributable to conservation measures have been

. derived by multiplying the amount of energy conserved by the applicable cost of fuel. Consideration has been given to the efficiencies of electric resistance, natural gas, and heat pump systems, as well as air conditioning systems, to render actual fuel bill impacts. The energy costs assumed are 1.54 cents per kilowatt hour and 55 cents per therm of natural gas. Additional assumptions required for the detailed cash flow analysis presented in Appendix $B$ are described there. 


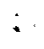

$\therefore$

.
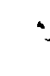


\subsection{Construction Techniques for Energy Efficient Buildings}

This section presents brief discussions of a variety of construction techniques that increase the energy efficiency of a building. The techniques described have been chosen because they do not represent radical departures from current building practice. Thus, this is not an all inclusive list of energy conserving options. Sources of much more extensive information are given in the bibliography.

\section{- 2.1 Heating System}

The type of heating system selected will affect the conditioning costs of a building due to differences in system efficiency, fuel costs and fuel cost escalation rates. This, in turn, impacts the energy savings and economic performance of most of the energy conservation features examined in this report. The heating systems evaluated in this handbook are an electric furnace, natural gas furnace and electric heat pump, which also serves as an air-conditioner. The discussions of conservation measures in this section assume heating is provided by an electric furnace unless otherwise noted. Analyses of the performance of the conservation measures in homes heated by natural gas and heat pumps are provided in Appendix B.

The electric furnace is the cheapest of the three alternatives to install and operates at almost $100 \%$ efficiency if the distribution ducts and furnace are within the living space or are well insulated. The $1500 \mathrm{ft}^{2}$ prototype house requires $11,286 \mathrm{kWh}$ annually to operate the $15 \mathrm{~kW}$ electric furnace. At the assumed electricity rate of 1.54 cents per $\mathrm{kWh}$ this would cost $\$ 174$ annually. If conservation measures reduce the peak heating load by $30 \%$ a $10 \mathrm{~kW}$ furnace would be sufficient, at a savings of $\$ 30$.

A natural gas furnace costs $\$ 300$ more than the electric furnace and operates at $70 \%$ efficiency, due to heat loss through the flue. The estimated 550 therms needed to heat a 1500 $\mathrm{ft}^{2}$ home would cost $\$ 303$ at $55 \mathrm{c} /$ therm. Since initial costs, as well as fuel costs, are higher for gas, it does not compare favorably with electricity on price alone in the mid-Columbia Region. If conservation measures are employed to reduce the peak heating load by $30 \%$, the gas heating system would cost $\$ 30$ less.

The heat pump is a very efficient heating device because it moves heat into the house from the exterior air, rather than creating heat. A quality heat pump will cost about $\$ 1,000$ more than an electric furnace with air conditioning, and has an efficiency range of $100 \%$ to $300 \%$, depending on the exterior air temperature. If an average coefficient of performance (COP) of 1.7 or efficiency of $170 \%$ is assumed, the system would require $6638 \mathrm{kWh}$ to heat the home at

- a first year cost of $\$ 102$. While fuel costs are low, compressor replacement is often required after 10 years.

- Projected fuel costs should be considered when a heating system is selected because that system is intended to operate for about 30 years. To help make this assessment, refer to Appendix B. 


\subsection{Air-Conditioner}

The air-conditioner selection and placement will affect conditioning costs significantly. The efficiency of air-conditioning units is dependent on the outside air temperature, but typically ranges from about $200 \%$ to $300 \%$, corresponding to coefficients of performance (COP) of 2 to 3 and energy efficient ratios (EER) of 7 to 10. The higher the ratings, the more efficient (and usually expensive) the system.

The air-conditioner condensor should be placed in a shaded location with good ventilation. Improper placement may reduce operating efficiency and life by as much as $50 \%$. The system should be inspected and cleaned annually and recharged as appropriate. In this area, the annual cooling costs for a $1500 \mathrm{ft}^{2}$ home were estimated to be $\$ 14$ using a 2.5 ton $(30,000 \mathrm{Btu})$ air conditioner to meet the peak cooling load. If the peak load can be reduced to 24,000 Btu, a 2 -ton system costing $\$ 110$ less would be sufficient. While evaporative type air coolers and other techniques may provide adequate cooling, these have not been evaluated.

\subsection{Wall Insulation}

Most state building codes call for a minimum $R$-value of 11 in building walls. This requirement can easily be accomplished by placing $3 \mathrm{in}$. of fiberglass insulation in the air space of $2 \times 4$ stud walls. Increasing the R-value above this level requires installation of insulated siding or styrofoam sheathing over $2 \times 4$ stud walls, or the use of $2 \times 6$ stud wall construction with 6 in. insulation blankets.

- Increasing the wall $R$-value is generally less costly with $2 \times 6$ framing than with sheathing or siding.

- The cost difference between R-11 and R-19 walls is mainly due to insulation rather than lumber costs. The increased spacing possible with $2 \times 6$ studs roughly offsets the higher cost of the lumber.

For a representative $1500 \mathrm{ft}^{2}$ home with an electric furnace, the costs and savings from insulating above the required $R-11$ level are given in Table 2 . Using the economic assumptions detailed later, R-19 wall insulation is generally best. The costs of insulating above that level are not offset by the value of fuel savings over a 30-year period.

Table 2. Effects of Increasing Wall Insulation Levels

\begin{tabular}{|c|c|c|c|c|}
\hline & $\begin{array}{c}\text { Additional } \\
\text { Cost }\end{array}$ & $\begin{array}{l}\text { Heating Load } \\
\text { Reduction } \\
\left(10^{6} \mathrm{Btu}\right)\end{array}$ & $\begin{array}{l}\text { Cooling Load } \\
\text { Reduction } \\
\left(10^{6} \mathrm{Btu}\right)\end{array}$ & $\begin{array}{c}\text { First Year } \\
\text { Energy Cost } \\
\text { Savings }\end{array}$ \\
\hline$R-11$ to $R-19$ & $+\$ 317$ & 10.3 & 0.7 & $\$ 48$ \\
\hline $\mathrm{R}-19$ to $\mathrm{R}-27$ & $+\$ 485$ & 3.1 & 0.2 & $\$ 15$ \\
\hline
\end{tabular}




\subsection{Ceiling Insulation}

The amount of insulation in the ceiling affects energy costs mainly because of its impact on heating loads. The minimum level allowable under most current building codes is R-19. The cost of increasing the level to $\mathrm{R}-30$ would be $14 \mathrm{C} / \mathrm{ft}^{2}$ and about $25 \mathrm{c} / \mathrm{ft}^{2}$ to $\mathrm{R}-38$. The costs and effects of these changes for a home with an electric furnace are shown in Table 3 . Using the economic assumptions discussed in Appendix B, the best level of ceiling insulation is R-19 for either an electrically heated or gas-heated home. The value of the energy saved by increasing insulation to R-30 or higher does not cover the additional cost within a reasonable time period.

\subsection{Reduction of Infiltration}

As the thermal integrity of a building increases, the effect of air leakage through the building shell (infiltration) constitutes a larger percentage of the total energy loss of the structure. For new residential buildings an hourly air change rate of 0.6 is typical. This means that $60 \%$ of the air within a house is exhausted to the exterior each hour on average. During cold periods large amounts of energy are needlessly wasted as the replacement air is heated to maintain comfortable interior conditions.

Some of the many places where air leaks into buildings are depicted in Figure 2. Although each one alone is unnoticeable except on the windiest of days they add up to a surprising amount of area. An average new house has a leakage area equivalent to a single hole of approximately $3 \mathrm{ft}^{2}$. Some homes have as much as four times this amount of leakage area. Since the cracks are actually distributed throughout the house, they are generally unnoticed.

- In mild climates such conditions may be acceptable or even beneficial, but in the MidColumbia climate high infiltration rates can lead to excessive heating costs.

In the $1510 \mathrm{ft}^{2}$ home analyzed in this study, air infiltration constituted approximately $55 \%$ of - the energy loss of the building, literally throwing over $\$ 100.00$ into the wind during the first year. This loss can be reduced relatively inexpensively by installation of a continuous vapor barrier, good quality weatherstripping, and attention to the construction quality. Homes with air exchange rates of less than 0.1 air change per hour are currently being constructed in Sweden and Canada where the climates are comparatively severe and utility rates high. 


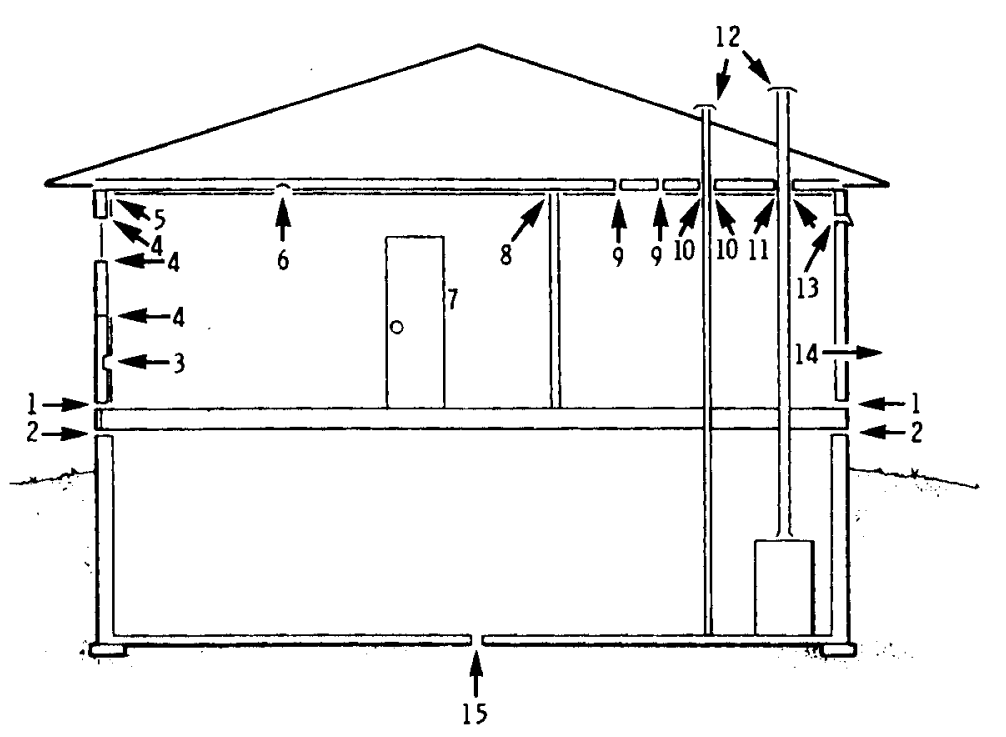

1. Joint between sill and floor

2. Joint between joists and basement

3. Electrical boxes

4. Joints at windows

5. Joints between wall and ceiling

6. Ceiling light fixture

7. Cracks at doors

8. Joints at interior partitions

9. Joints at attic hatch

10. Plumbing stack penetration

11. Chimney penetration of ceiling

12. Chimney leaks air from house continuously

13. Vents from bathroom and kitchen

14. Holes through vapor barrier tears

15. Floor drain lair enters via

weeping tile)

Figure 2. Air Leakage Spots in Conventional Construction

Significant concerns have surfaced regarding deterioration of interior air quality as infiltration is reduced below 0.2 air changes per hour. Uncomfortable or unhealthy air quality conditions can be remedied by installation of an efficient air-to-air heat exchanger costing less than $\$ 300.00$. Such a device allows the occupants to select an appropriate ventilation rate while conserving $85 \%$ of the heat that would otherwise be lost through exfiltration. Air quality problems are unlikely to occur with the measures suggested in this manual. Rather extreme measures must be employed to reduce infiltration to the point where a building is unhealthy.

Vapor barriers can be a crucial element in insuring that a building is air tight as well as vapor tight. The recommended vapor barrier for walls, ceilings, and floors is 6 mil polyethylene sheet, which is continuously sealed at all joints. A durable sealant that has proven successful is acoustical sealant, a type of modestly priced non-hardening material that is readily available in cartridges for caulking guns. Caulking material that will harden and peel away from the polyethylene sheet or crack should not be used, since this will defeat the purpose of the caulking.

The vapor barrier must be installed on the interior (warm) side of the insulation to limit condensation in the insulation. Careful handling of the membrane is required to prevent damage that will reduce its effectiveness. Particular attention should be given by drywall installers to avoid ripping the barrier. Detailing around electrical boxes, plumbing, doors, windows, and other penetrations is important to insure the integrity of the vapor barrier.

If $2 \times 6$ framing is used it is recommended that the top and bottom of the studs be grooved to accomodate the electrical or plumbing conduit. This simplifies the installation of wall insulation and continuous vapor barriers by avoiding "bumpy spots" where the conduit lies. When a continuous vapor barrier is installed, use of unbacked insulation is best. Detailing around 
electrical boxes and other wall penetrations can be simplified by using commercially available vapor barrier pans as depicted in Figure 3. Particular attention must be given to the intersection of the vapor barrier with structural members. Figure 4 provides details of the ceiling-wall interface and the wall-floor junction. The barrier installation procedure for a wall-ceiling junction is shown in Figure 5 . The point is to achieve a continuous seal across the entire surface from ceiling to floor.

Windows and doors should be of sufficiently high quality to be effectively sealed in their frames. Care must be taken to insure that the frames are properly installed in the wall with attention paid to the detailing of the vapor barrier installation. This detail is shown in Figure 6. A suggestion for an energy-conserving attic hatch installation that is frequently overlooked is provided in Figure 7.

$\therefore \quad$ Vapor/air barriers do not require expensive materials or exotic technology, but conscientious construction management. The results are not visually apparent, but the resultant energycost savings can be substantial. If a vapor barrier is installed and the seller stresses the care and attention to detail that went into the finished product, it may improve the marketability of the building to first and subsequent buyers.

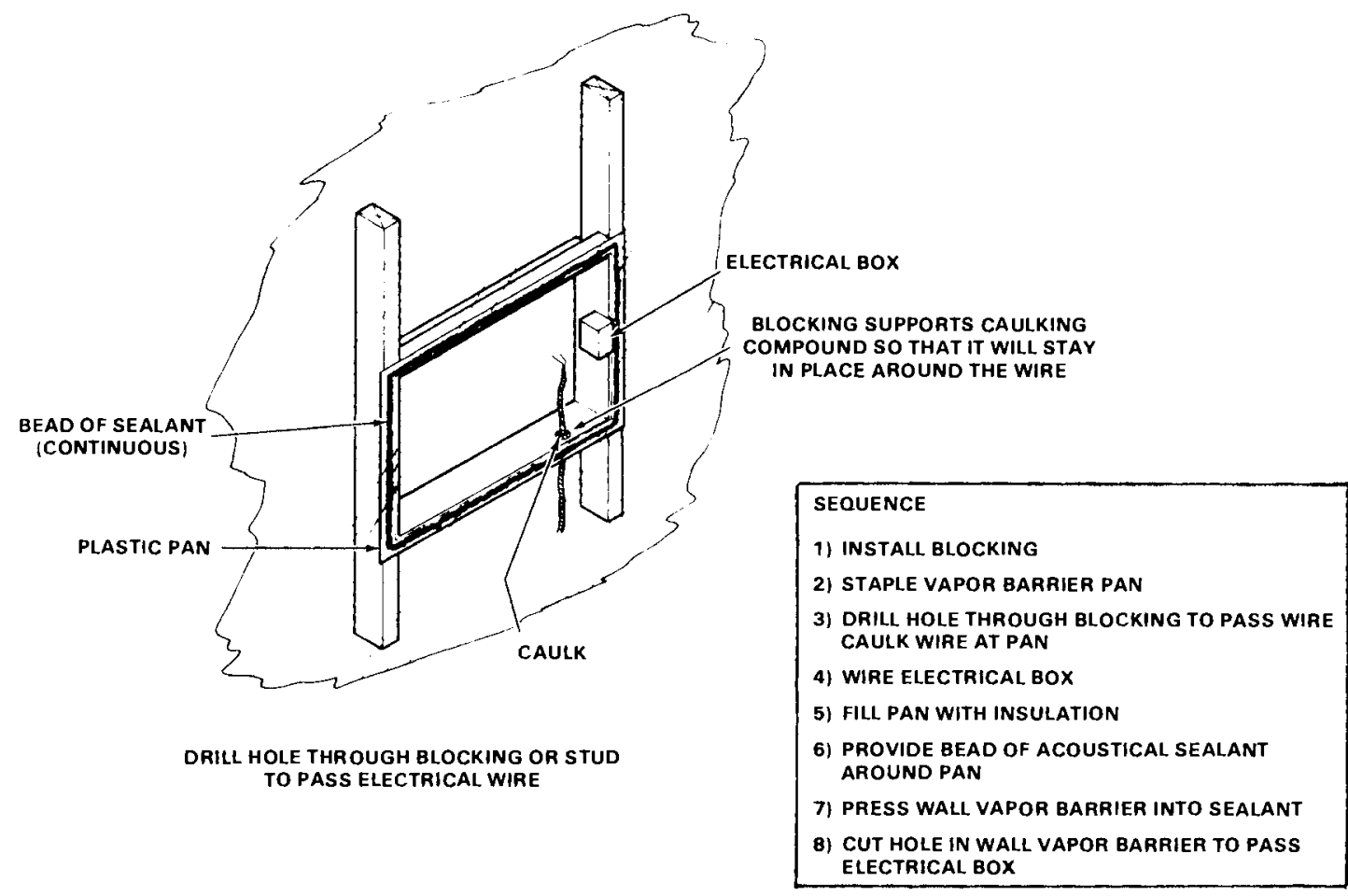

Figure 3. Use of Vapor Barrier Pans 


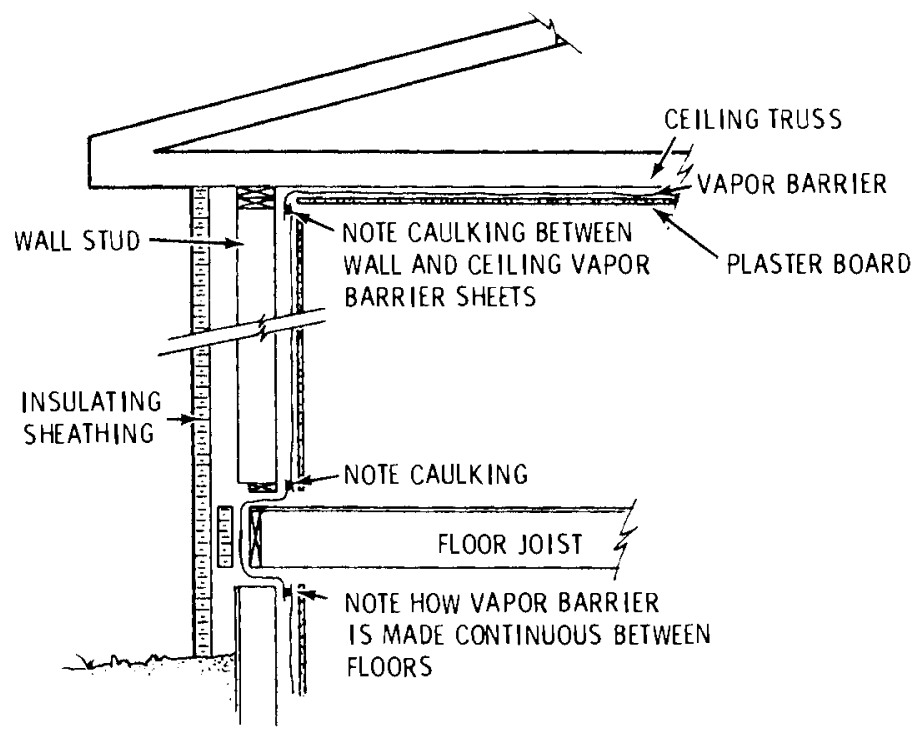

WALL SECTIONS EXPANDED

TO SHOW VAPOR BARRIER DETAIL

Figure 4. Vapor Barrier Details Cross-Section View

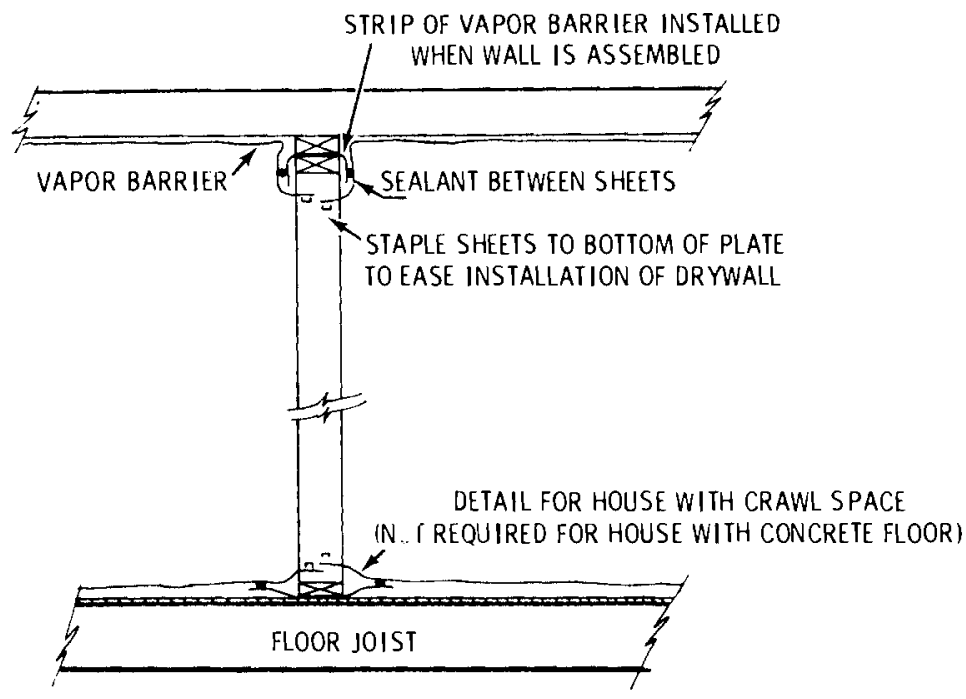

Figure 5. Vapor Barrier Installation for Partition Wall (Cross-Section View) 


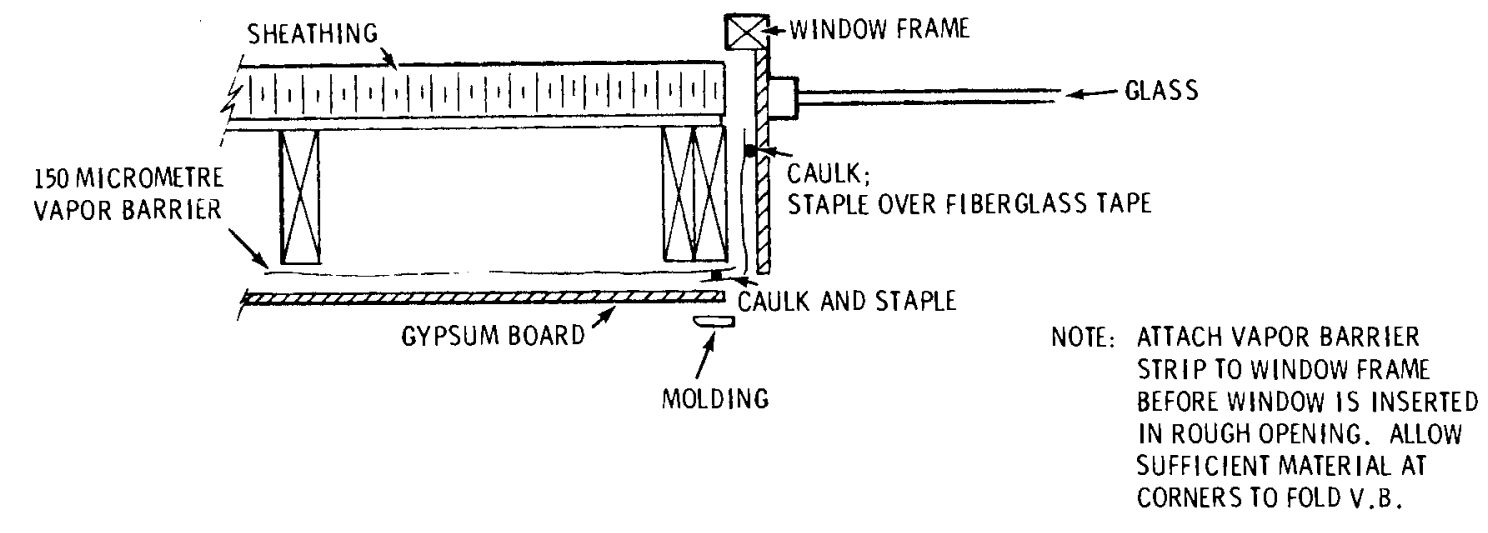

Figure 6. Vapor Barrier Installation at Window (Section View Looking Down)

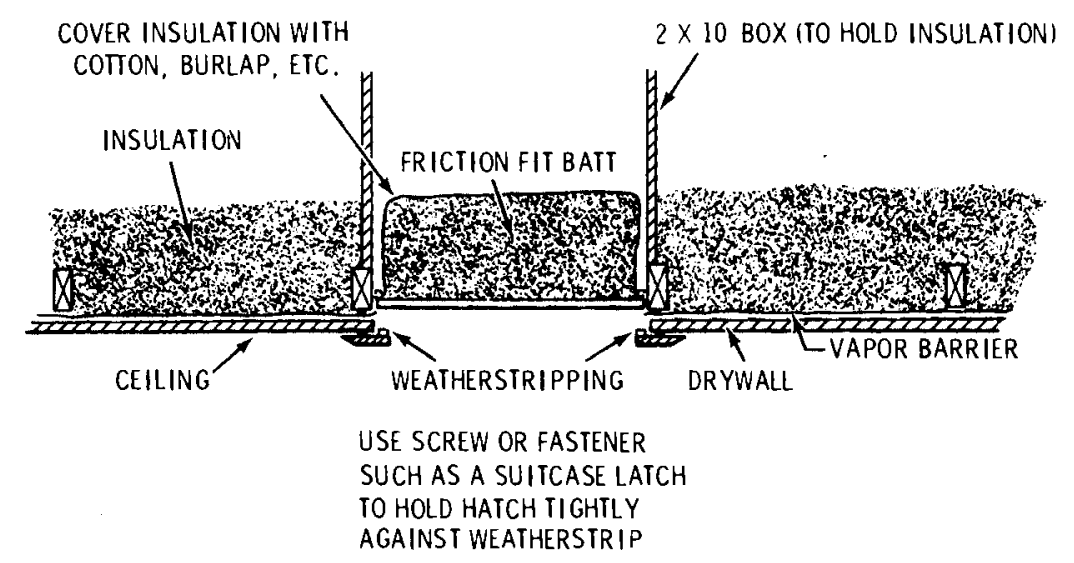

ALTERNATIVE: USE HATCH ON GABLE END, ROOF, OR GARAGE RATHER THAN IN CEILING.

Figure 7. Attic Hatch Detail

\subsection{Floor Insulation}

The ideal level of insulation for building floors is difficult to determine due to variations in - building design, ground temperature profiles, and other site specific issues. Since computer models of the thermal behavior of floors have not been thoroughly validated, the following information is based upon engineering judgment. The discussion covers three predominant types of floors used in residential construction: concrete slab, basements, or wooden joists over crawl spaces. 
For concrete slabs the use of rigid insulation around the entire perimeter is recommended. The material should have an $R$ rating of 10 or better: 2 in. expanded polystyrene is commonly used. The insulation should cover the area from about 2 in. above the exposed slab to slightly below the frost-line (probably 2 to $3 \mathrm{ft}$ in depth would be best). The use of insulation directly beneath the slab is not recommended as compression and subsequent cracking may result.

For basement walls the appropriate strategy depends on whether or not the space is intended to be conditioned. If not conditioned, insulation of the grade level floor to R-11 is economically advisable. If the basement is to be used as conditioned space, the exterior wall surface should be covered with 2 in. expanded polystyrene. The recommended depth depends upon the desired temperature of the basement space. If temperatures of 55 to $60^{\circ} \mathrm{F}$ are acceptable the insulation need only go about $3 \mathrm{ft}$ deep. If greater temperatures are desired the entire basement wall should be insulated.

For floors over vented crawl spaces the insulation levels should be close to the wall insulation level so in this area use of R-19 insulation is recommended. This can be installed in one of two ways, either directly to the grade level floor or to the crawl space walls and sill plate when used in conjunction with a vapor barrier covering the crawl space floor. In new construction the first procedure is recommended to avoid the risk of vapor barrier damage and facilitate accessibility to the crawl space.

\subsection{Insulated Doors}

The thermal performance of a metal door with a polyurethane core was compared to that of a decorative solid wood door.

- The effective R-value of the insulated door is 13.5 compared to an R-value of 1.5 for the solid wood door.

- The insulated metal door costs the same or less than the solid wood door.

- The metal door should outlast the wooden door.

- The metal door is more resistant to warpage and should permit less air infiltration.

In an average house, each metal door would save $795,000 \mathrm{Btu} /$ year or about $2 \%$ of annual heating and cooling costs. At 1980 fuel prices, the annual savings is $\$ 3.59$ for an electrically heated home, $\$ 6.00$ for a gas heated home and $\$ 2.11$ for a home with a heat pump. Actual savings will probably be greater because the metal door is more effective at minimizing infiltration if the weatherstripping is not damaged.

\subsection{Storm Doors}

Storm doors affect the energy use of a structure in two ways: by increasing the R-value of the exterior doors and by reducing the rate of infiltration through them. Installation of storm doors reduces the air exchange rate by $10 \%$ and increases the $R$-value of an insulated door from 13 to 16. The annual total effect of storm doors over insulated doors is to reduce heating loads by 2.3 million Btu, cooling loads by 0.26 million Btu, and energy costs by $\$ 11$. 
If a decorative wood door is selected, the benefit of adding a storm door is even greater. The $R$-value of the door is increased from 2.2 to 5.2 , reducing annual heating and cooling costs by
$\$ 14$. The storm door will also reduce the weathering and resulting warpage of a wooden door.

\subsection{Window Glazing}

Double-glazing is now required by code in both Washington and Oregon. Installing tripleglazed windows instead is to the homeowner's advantage because the energy and cost savings are substantial. Double-pane has an R-value of 1.86, due in part to the enclosed air space, and allows $75 \%$ of the incident solar radiation to enter. Triple-pane windows have an $R$-value of 3.05 but permit only $65 \%$ of the incident solar radiation to enter.

... : Triple glazing offers the following advantages over double glazing:

- reduces heating loads by 9.7 million Btu and cooling loads by about 1 million Btu

- permits use of smaller conditioning system in some homes

- has an average net cost of $\$ 311$ for a $1500 \mathrm{ft}^{2}$ home

- saves $\$ 46.00$ on first year energy cost for a home with an electric furnace.

Based on the economic criteria used in this study, triple glazing of windows is the best option in this climate. The heat transfer through windows can also be affected by numerous strategies incorporating the use of movable insulation and awnings. These strategies are discussed in detail in the following sections.

\subsection{Operable Windows}

By opening windows and venting the living space with cool outside air when practicable, the costs of cooling a home can be reduced. The homes have been simulated, assuming that a rational occupant opens the windows when appropriate. If such action were not taken, cooling requirements would increase by 3.3 million Btu/year, which increases cooling costs by $19 \%$. Since this strategy affects cooling costs only, a first year savings of $\$ 2.68$ results, regardless of the heating system type. Operable windows can possibly result in higher infiltration than would occur with fixed windows, although if good quality windows are used, this effect should be small.

- The window style can impact the degree to which air is circulated through the house during temperate periods. Outward projecting casement windows parallel to the dominant winds can

- scoop in and exhaust air effectively. Top-hinged, bottom-hinged, and center-pivoting windows angle the incoming air stream upward in the plane of the sash, thus moving otherwise stagnant hot air near the ceiling. Double-hung windows induce ventilation because less

- dense warm air can be exhausted through the top side while cooler air is drawn in through the bottom opening. 


\subsection{Window Framing}

The window frame can enhance or detract from the beneficial energy attributes of a window. The material from which it is constructed can be insulating or can be highly conductive and prone to condensation problems. Air infiltration can be a problem with operable windows especially. Weatherstripping between operable sash and the frame can substantially impede infiltration through the joint cracks at the perimeter of the window.

Generally window infiltration occurs at three joints:

1) the perimeter joint between the frame and the wall

2) the perimeter joint between the sash and the frame

3) the perimeter joint between the glass and the sash.

Particular attention should be given to the construction detail of windows in these joints . Installation of the frame with continuous vapor barrier as described in the infiltration discussion is highly recommended. Since all these infiltration paths occur in perimeter areas, it is advantageous to use large windows in preference to multiple small ones. In general, wood framed windows are less subject to infiltration problems than metal framing due to the depth of the framing material. On either type, infiltration can be reduced $50 \%$ by proper weatherstripping.

Heat transfer through the frame must also be considered. Aluminum conducts heat 1,770 times better than wood and therefore offers relatively little resistance to unwanted heat flow. This inherent disadvantage of metal window frames can be alleviated by thermally separating the inside of the frame from the outside. There are presently two methods of providing thermal separation:

1) pouring poly-urethane in a slot in the metal frame and then, after it has bonded and set, sawing away the metal bridging the slot,

2) providing two separate frames linked together by a rigid vinyl insert.

An aluminum frame with a good thermal break has a U-value similar to insulating glass and performs substantially better than an aluminum frame without such a break. Since the frame area may comprise as much as $20 \%$ of the total window area, it is important that a framing with a thermal break be used. The added cost is about $10 \%$ per window, which is generally repaid within three years through fuel cost savings.

\subsection{Specialized Window Glazings}

Low-emissivity, reflective, tinted, and heat absorbing glazings are available. Most of these items serve to limit heat gain, which is not a predominate concern in this climate. However, if overheating conditions occur frequently, such glazings may be useful in mitigating the problem. Their use in residential buildings is not recommended in this area because the amount of heat rejected in the summer is offset by the diminished solar collection during the heating season. As this goes to print, application of new films has been shown to decrease by $60 \%$ heat loss through double glazing. The cost is about $\$ 3.00 / \mathrm{ft}^{2}$ but varies with the brand chosen. 


\subsection{Window Orientation}

Window orientation impacts a building's energy use because of solar radiation, which provides daylighting and warmth. In the houses analyzed, heat losses through the $212 \mathrm{ft}^{2}$ double-glazed windows accounted for over $20 \%$ of the heat loss on the winter design day, and unwanted heat gains through windows during the summer design day accounted for nearly $40 \%$ of the cooling loads. Since full sunlight has an average heat intensity of over 450 $\mathrm{Btu} / \mathrm{ft}^{2} / \mathrm{hr}$, facilitating its entry into the building when heat is required and blocking it when overheating might occur is highly advantageous. Such use of the sun's energy is popularly called passive solar design.

In the Mid-Columbia Region the sun's path changes dramatically from winter to summer

$\therefore$ months. In June the sun rises $30^{\circ}$ north of east at $4: 30$ am, reaches an altitude of $70^{\circ}$ at noon and sets $30^{\circ}$ north of west at $8: 30 \mathrm{pm}$. At the other extreme in December the sun rises at $7: 00$ am at $30^{\circ}$ south of east, reaches a maximum altitude of $22^{\circ}$ and sets $30^{\circ}$ south of west at 4:00 pm. Skillful placement of windows and fixed shading devices can capitalize on this natural variation in the sun's path to significantly reduce conditioning costs.

Window performance has been compared to performance of an R-19 wall that those windows are assumed to replace in various orientations. Because the $R$-value of double glazing is only about $1 / 10$ that of the stud wall replaced, the heat losses by conduction are increased. Over a typical heating season, the loss amounts to $54,000 \mathrm{Btu} / \mathrm{ft}^{2}$ of glass, but is offset to varying degrees by the solar radiation admitted by the glass. The net impact on heating loads that results from substituting windows for stud walls is presented in Figure 8 for double glazing and Figure 9 for triple glazing.

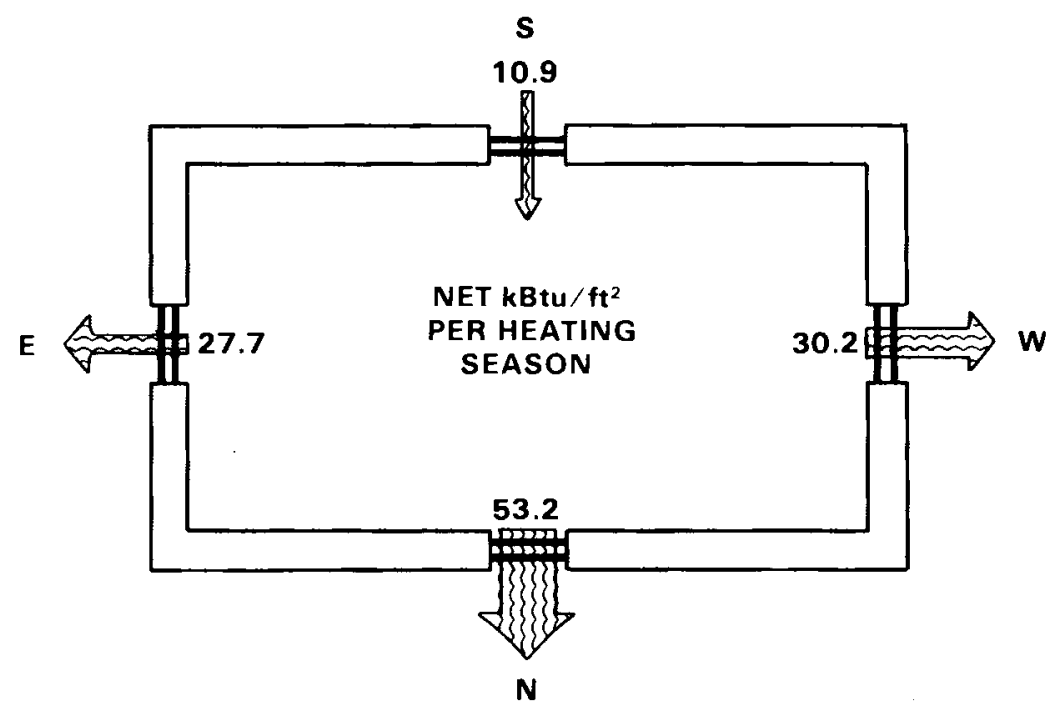

AVERAGE TOTAL HEAT LOAD IS $25.7 \mathrm{kBtu} / \mathrm{ft}^{2}$ PER HEATING SEASON

Figure 8. Heat Flow Through Double Glazing Compared to R-19 Stud Wall (Average Total Heat Load is $25.7 \mathrm{kBtu} / \mathrm{ft}^{2}$ Per Heating Season) 


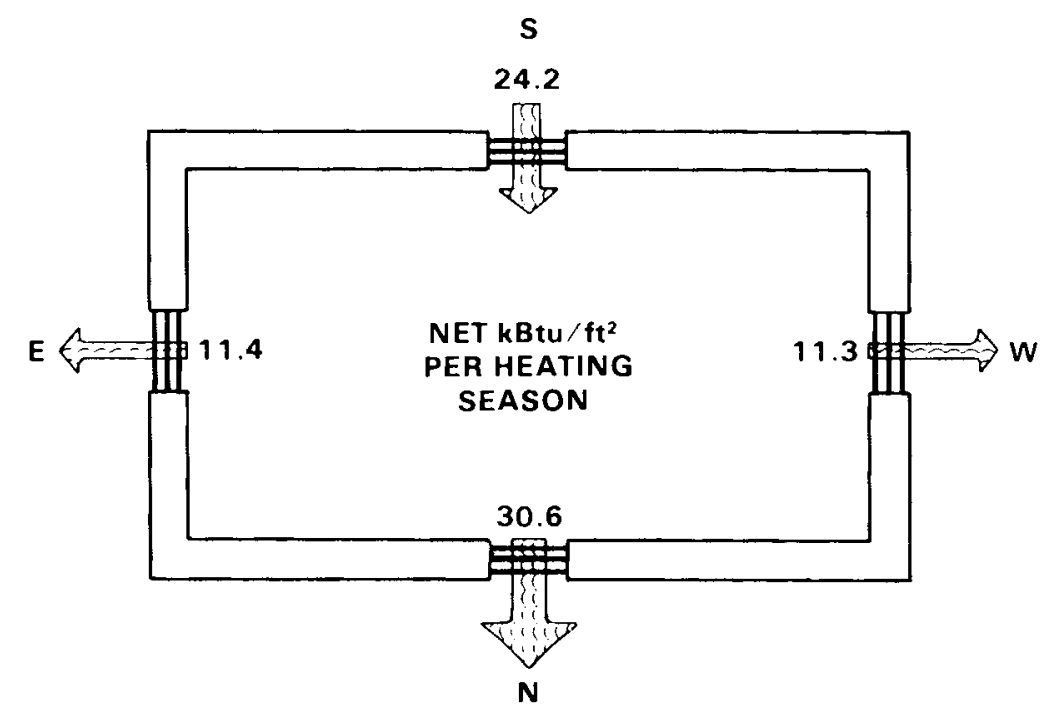

AVERAGE HEAT LOAD IS $23.0 \mathrm{kBtu} / \mathrm{ft}^{2}$ PER HEATING SEASON

Figure 9. Heat Flow Through Triple Glazing Compared to R-19 Stud Wall (Average Heat Load is $23.0 \mathrm{kBtu} / \mathrm{ft}^{2}$ Per Heating Season)

As Figure 8 indicates, the placement of double-glazed windows in the south wall brings a net average of $10,900 \mathrm{Btu} / \mathrm{ft}^{2}$ into the building over the heating season because the south windows collected $64,900 \mathrm{Btu}$-worth of solar energy gain $/ \mathrm{ft}^{2}$, yet lost only $54,000 \mathrm{Btu}$ more than the stud wall. The savings is even more pronounced for south-facing triple-glazed windows, where a net gain of $24,200 \mathrm{Btu} / \mathrm{ft}^{2}$ results. For a home with electric resistance heating, this results in an annual savings of about $7 \mathrm{kWh} / \mathrm{ft}^{2}$.

While double-glazed south windows reduce heating requirements, windows facing north, east and west do not perform nearly as well because they cannot collect sufficient solar radiation during the winter months to offset the conduction losses. Double-glazed windows increase heating loads by $27,700 \mathrm{Btu} / \mathrm{ft}^{2}$ in east walls and by $30,200 \mathrm{Btu} / \mathrm{ft}^{2}$ in west walls. North windows are by far the worst energy performers, losing over $53,000 \mathrm{Btu} / \mathrm{ft}^{2}$ more than the section of stud wall replaced. If the heating loads alone are considered, the movement of a square foot of double glazing from the north to the south wall results in a savings of 64,100 Btu, or approximately $19 \mathrm{kWh}$ /year in a house heated by electric resistance.

Substituting windows for stud walls increases cooling loads slightly. A double-glazed window gains 7,500 Btu/ $\mathrm{ft}^{2}$ per cooling season by conduction, and direct and diffuse solar energy contributes some heat gain also, depending on window orientation and shading. Assuming no shading, this gain ranges from $2,500 \mathrm{Btu} / \mathrm{ft}^{2}$ for north windows; $25,100 \mathrm{Btu} / \mathrm{ft}^{2}$ for west windows; $23,900 \mathrm{Btu} / \mathrm{ft}^{2}$ for east windows; and $21,700 \mathrm{Btu} / \mathrm{ft}^{2}$ for south windows. Undesirable collection of solar radiation may be effectively controlled with external shading devices such as overhangs, awnings, and deciduous plants. 
South windows obviously greatly outperform windows in other orientations from an energy standpoint. Window placement on south walls should be considered whenever possible since little or no incremental cost is involved compared to window placement on any other wall. Varying window orientation by less than $20^{\circ}$ from the cardinal directions analyzed will probably not affect performance significantly. Of course, some windows will be necessary in other locations for egress, view, and daylighting requirements, but the designer or builder should keep in mind the energy impacts of such actions.

\subsection{Building Shade}

In most climates, an overhang above the south facing windows can reduce conditioning loads by blocking the summer sun. However, in this climate since heating is typically required into May and cooling through September, reductions in cooling loads due to roof overhangs are offset by additions to heating loads. The use of adjustable shading devices such as awnings, which would admit the early May sun and block sun through September, can reduce cooling costs by approximately $\$ 5.00$ annually without adversely affecting heating loads. In addition, such devices provide protection from uncomfortable glare and allow the occupant more flexibility in daylighting the home. These energy-cost savings are small but may reflect improvement in the comfort of occupants as well.

The judicious placement and selection of deciduous trees can also be advantageous. The trees not only shade the house beneficially, but also effectively cool the building micro-climate because of evaporation from the leaves. The ambient air temperature surrounding a wellshaded structure is estimated to be $10^{\circ}$ cooler than the unshaded environment on a calm day. The effect of evaporation translates into a cooling cost savings of approximately $\$ 5.00$ at current rates ( 2.6 million Btu). Tall shade trees with long trunks should be placed close to the south wall of the home to permit the low-lying winter sun to reach the building and to offer shade from the high summer sun. Trees that would effectively block summer sun from the east and, more importantly, the west windows, would also be advantageous. Assuming that the shade trees effectively block $85 \%$ of the summer sun and only $10 \%$ of the winter sun (due to limbs and trunks), the net effect is to increase heating costs by $\$ 4.50$ and reduce cooling costs by $\$ 10.00$ for a net savings of $\$ 5.50$.

\subsection{Night Setback Thermostat}

The energy savings from a night setback thermostat depend upon the set point and duration of the setback. The effect is the same as that obtained with a manual setback ther mostat, with the advantages of convenience and reliability. The additional cost of the automatic model is about $\$ 40$ with a first year savings of about $\$ 30$ to be expected in a home with an electric furnace system. Table 4 gives information on energy and cost savings for various setback periods and set points. Reducing the setback temperature below $55^{\circ}$ has minimal impact on the conditioning costs, while increasing the duration by three hours increases savings by about one-third. 
Table 4. Night Setback Thermostat Effects

\begin{tabular}{|c|c|c|c|c|c|}
\hline \multirow{2}{*}{$\begin{array}{l}\text { Setback } \\
\text { Setting }\end{array}$} & \multirow{2}{*}{$\begin{array}{c}\text { Setback } \\
\text { Period (hr) }\end{array}$} & \multirow{2}{*}{$\begin{array}{c}\text { Heating Load } \\
\text { Reduction } \\
10^{6} \mathrm{Btu} \\
\end{array}$} & \multicolumn{3}{|c|}{ Value of First Year Energy Savings $\$$} \\
\hline & & & Electric & Natural Gas & Heat Pump \\
\hline \multirow[t]{2}{*}{$50^{\circ}$} & $12-7$ & 4.18 & 19.00 & 33.00 & 11.00 \\
\hline & $10 \cdot 8$ & 5.48 & 25.00 & 43.00 & 15.00 \\
\hline \multirow[t]{2}{*}{$55^{\circ}$} & $12-7$ & 4.17 & 19.00 & 33.00 & 11.00 \\
\hline & $10-8$ & 5.47 & 25.00 & 43.00 & 15.00 \\
\hline $60^{\circ}$ & $12-7$ & 3.97 & 18.00 & 31.00 & 11.00 \\
\hline
\end{tabular}

\subsection{Flue Damper}

Installing an automatic flue damper in a natural gas furnace will reduce heating costs by about $10 \%$ by impeding the heat flow through the flue when the furnace is off. A reliable flue damper is expected to save 55 therms per year in a $1500 \mathrm{ft}^{2}$ house or about $\$ 30$ in the first heating season. The cost of an automatic damper is about $\$ 180$, installed.

\subsection{Wood Stoves/Fireplaces}

The cost-effectiveness of wood stoves and fireplaces as alternatives to conventional heating depends on a variety of factors, including the price of wood, the density and moisture content of the wood, the efficiency of the wood stove or fireplace, and the price of conventional fuels. A brief discussion of these factors, along with a cost-effectiveness calculation for "average" wood stoves and fireplaces, is presented below.

Wood is not a uniform fuel source like electricity or natural gas. While the heat content of a pound of oven-dried wood is generally assumed to be fairly constant (about $8600 \mathrm{Btu} / \mathrm{lb}$ ), actual heat obtained from burning the wood can vary considerably. The resin content of the wood increases its heat content because resin burns hotter than wood. Moisture content on the other hand, decreases the heat content because some of the heat is consumed to vaporize the moisture. This means that green wood will generate less heat than dry wood. Thus, while oven-dried wood has a heat value of $8600 \mathrm{Btu} / \mathrm{lb}$, air-dried wood, which contains about $20 \%$ moisture, will produce only about $7700 \mathrm{Btu} / \mathrm{lb}$ of heat when burned.

Wood is generally purchased by the cord, a 4-ft $\times 4-\mathrm{ft} \times 8-\mathrm{ft}$ stack of wood. The energy content of a cord of wood depends not only on resin and moisture, but also on how tightly the wood is stacked and how dense the wood is. Generally, a cord contains 60-100 $\mathrm{ft}^{3}$ of wood that can range in weight from about 30 to $45 \mathrm{lb}$, depending on the species. Hardwoods tend to produce more energy than softwoods due to their greater density. This density is partially offset, however, by the higher resin content of softwoods. 
The cost-effectiveness of burning wood strongly depends on the efficiency with which it is burned. An airtight wood stove is capable of efficiencies around 50\%; that is, one-half of the heat content of the wood will be delivered to the living space, while the rest goes up the chimney. Open fireplaces are generally much less efficient than wood stoves. In fact, a net heat loss can occur in fireplaces that draw air for combustion from the living space. The fireplace can actually draw more heat out of the house in the form of warm air than it radiates into the house. Outside air intake vents, glass doors, and air circulators can greatly improve the performance of a fireplace. However, even with these modifications fireplace efficiencies generally range from zero to $15 \%$.

Table 5 shows heating costs for $20 \%$ moisture Douglas fir, which has about 19.2 million Btu/cord. This tables shows what cost per therm or kWh would result in the same cost of delivering heat to the living space as a $50 \%$ efficient wood stove or a $15 \%$ efficient fireplace with wood at various prices. These cost equivalents represent the price of electricity that would make wood heating economically equal to electric or gas heat. For example, where electricity costs $1.54 \mathrm{c} / \mathrm{kWh}$, a wood stove would be economical for wood prices up to about $\$ 45 /$ cord.

A fireplace is a more expensive source of heat than electricity at current prices, unless the wood is much less expensive than $\$ 25 /$ cord. This might be the case if scrap wood is used or the homeowner cuts his/her own firewood and figures no cost for labor.

Table 5. Cost Equivalents for Wood, Electric Furnace or Gas Heating

\begin{tabular}{|c|c|c|c|c|}
\hline \multirow{3}{*}{$\begin{array}{c}\text { Price of } \\
\text { Wood } \\
\text { (\$/Cord) }\end{array}$} & \multicolumn{4}{|c|}{ Cost of Delivered Heat } \\
\hline & \multicolumn{2}{|c|}{ From a Wood Stove(a) } & \multicolumn{2}{|c|}{ From a Fireplace(b) } \\
\hline & $c / k W h$ & $\mathrm{c} /$ therm & c/kWh & $\mathrm{c} /$ therm \\
\hline 25 & 0.88 & 18.2 & 2.9 & 60.8 \\
\hline 50 & 1.78 & 36.4 & 5.9 & 121.5 \\
\hline 75 & 2.68 & 54.7 & 8.9 & 182.3 \\
\hline 100 & 3.56 & 72.9 & 11.9 & 243.1 \\
\hline 125 & 4.46 & 91.2 & 14.9 & 303.8 \\
\hline
\end{tabular}

(a) Wood stove is assumed to be $50 \%$ efficient.

(b) Fireplace is assumed to be $15 \%$ efficient.

\subsection{Hot Water System}

A household can reduce its overall energy consumption by reducing the amount of energy used to heat household water. This reduction can be achieved by installing an efficient water heater, by adding insulation to the hot water tank and/or pipes located in unheated spaces, or 
by shortening the hot water pipes. If the water tank is located inside the heated space, insulating it will save no energy during the winter since the escaping heat merely serves to heat the house. However, it must be recognized that during the summer, any heat lost by the water heating system would increase the household cooling load. Because the cooling load for most homes in the Mid-Columbia Region is relatively small, this effect would probably be negligible.

Reductions in energy usage can also be achieved through installation of a variety of watersaving devices that enable the user to obtain the same amount of convenience while using less hot water. Shower-flow restrictors, low-flow shower heads, faucet aerators, pressurereducing valves, thermostatic mixing valves, water-saving dishwashers and clothes washers, and air-blower showers are examples of such devices, some of which are quite inexpensive. For instance, shower flow restrictors and faucet aerators are available for a few dollars and can be easily installed. In fact, many utilities offer shower flow restrictors free to the ir customers. However, water-saving devices can also be very expensive. An air blower shower, for instance, costs $\$ 500$ installed. Water-saving dishwashers and clothes washers sell for $\$ 200-\$ 300$, the same price or only slightly more than conventional models. They are, therefore, a viable energy conservation option in houses equipped with these appliances. Option costs and energy savings estimates are provided in Table 6.

Table 6. Hot Water System Energy Conservation Options

\begin{tabular}{|c|c|c|c|c|c|c|}
\hline Water-Saving Device & $\begin{array}{l}\text { stimated Water } \\
\text { Savings for a } \\
\text { Family of } 4 \\
\text { (gal/yr) }\end{array}$ & $\begin{array}{l}\text { Average Water } \\
\text { Temperature } \\
\text { (F) }\end{array}$ & $\begin{array}{l}\text { pproximately } \\
\text { Installed } \\
\text { Unit Cost } \\
\text { (1980 \$) }\end{array}$ & $\begin{array}{c}\text { Annual Energy } \\
\text { Savings } \\
\text { (kWh/year) }\end{array}$ & $\begin{array}{c}\text { Energy Cost } \\
\text { Saving at } \\
1.54 \mathrm{c} / \mathrm{kWh} \\
\text { (\$/Year) } \\
\end{array}$ & \\
\hline Shower Flow Restrictor & 10,400 & 107 & 1 & 1,320 & 20.33 & \\
\hline $\begin{array}{l}\text { Low-Flow Shower Head } \\
\text { Faucet Aerators }\end{array}$ & 14,560 & 107 & 15 & 1,849 & 28.47 & \\
\hline (Kitchen/Bath) & 730 & 105 & $3(1.5 \times 2)$ & 89 & 1.37 & \\
\hline Pressure Reducing Valve & 4,380 & 104 & 35 & 524 & 8.07 & \\
\hline Thermostatic Mixing Valve & 2,290 & 107 & 110 & 371 & 5.71 & \\
\hline $\begin{array}{l}\text { Water-Saving Dishwasher } \\
\text { Water-Saving }\end{array}$ & 1,460 & 140 & $250(a)$ & 303 & 4.67 & \\
\hline Clothes Washer & 3,650 & 100 & 200(a) & 401 & 6.18 & \\
\hline Air Blower Shower & 18,200 & 107 & 500 & 2,311 & 35.59 & $\therefore$ \\
\hline
\end{tabular}




\subsection{Solar Water Heating}

Although solar water heating systems perform well in the Mid-Columbia climate, they do not pay off quickly because system costs are high and electricity is relatively inexpensive. A system that provides $70 \%$ of the annual water heating requirement for a family of 3 or 4 persons would require $75 \mathrm{ft}^{2}$ of collectors and cost approximately $\$ 2,500$ installed. The average family uses $4515 \mathrm{kWh} /$ year to heat water at a cost of $\$ 70$, or 220 therms of gas at a cost of $\$ 121$. The cost savings resulting from the $70 \%$ solar water heating system would be $\$ 49$ and $\$ 85$, respectively. Based on those economic assumptions, solar water heating would not be cost-effective unless the total cost was less than $\$ 1,000$. Such costs to the homeowner may be achievable in the near future, due to decreasing installation costs and various tax incentive programs.

\subsection{Exterior Color}

The exterior color of a building affects energy requirements because darker colors absorb a larger percentage of the incident solar radiation. The effect on annual heating and cooling requirements is slight however, because reductions in heating loads caused by darker colors are largely offset by increases in cooling loads. If the color of a building roof and walls is changed from an ivory white to a dark grey, the annual energy requirements decrease slightly (approximately $1.4 \%$, or $\$ 2.50$ for an electrically heated home). It should be noted that the impact of color on energy use decreases as the level of insulation in ceilings and walls increases. For energy-efficient buildings, the exterior color affects aesthetics more than energy use, although in the Mid-Columbia climate dark colored walls and light roofs are preferable.

\subsection{Building Interior}

The interior construction and finishing of a structure affect the energy required to maintain comfortable interior conditions. The color, location, and height of interior partitions will determine how deeply daylight penetrates the rooms, thus affecting the amount of artificial lighting required. Interior structures may also be used to store solar heat during periods of excess to be reradiated later when the room temperature drops. A massive floor and wall in the path of the sunlight can effectively perform this function.

- The building designer should exercise care in the placement of windows, so that they provide light to areas normally utilized during the daytime. Use of clerestory windows can facilitate the penetration of light to the north side of a building through south facing windows. The use of skylights is not recommended unless provisions are made to shade them during the summer to limit overheating problems.

Fluorescent fixtures provide lighting twice as efficiently as the incandescent type and thus should be used where practicable. The use of dimmer switches can reduce the energy use of incandescent fixtures and allow the occupant flexibility in the setting of interior lighting levels. Task lighting focused upon work areas can provide concentrated light where necessary without needlessly overlighting adjacent areas. 
Interior surfaces should be painted a light color to increase the light level possible from lighting. White walls reflect 80 to $90 \%$ of incident light while yellow walls reflect only $35 \%$ and medium blue or green walls reflect from 20 to $30 \%$. Desirable reflection levels from ceilings and walls are $80 \%$ and from floors $25 \%$.

Massive materials placed directly in the path of winter sunlight transmitted through windows will store part of the incoming solar heat for subsequent radiation to the interior during non-sunlight hours. However, large windows, especially in small rooms, can transmit so much solar radiation that overheating may occur during periods of peak solar intensity. This can be remedied by placing massive materials such as concrete floors or walls, water filled barrels, or thermal storage rods in the path of the sunlight. When the room temperature drops, the heat accumulated in the materials is radiated to the interior, thus decreasing loads on the conditioning system.

A material's effectiveness in storing heat can be judged from its ability to absorb sunlight, conduct surface heat to its mass, and hold the resulting heat. Dark surfaces absorb from 80 to $90 \%$ of the solar radiation incident upon them while light surfaces absorb less than $30 \%$. Concrete and water are among the best commonly available heat storage materials. Thermal storage rods, using phase change materials to release heat at about $80^{\circ}$, are currently available but are relatively expensive currently.

Table 7 can be used as a guideline to roughly approximate how much mass should be provided to store a window's solar heat. Different areas of materials are given for different thicknesses of concrete and allowable inside temperature swing. During the winter months in this area an average of approximately $1000 \mathrm{Btu} / \mathrm{ft}^{2} /$ day is available through vertical south facing windows.

If water is used for storage, the volume of mass required is $38 \%$ of the concrete volume. The incorporation of mass into the structure has the benefits of increasing the utility of solar energy transmitted through the windows, delaying daytime temperature rise during the summer, and reducing cycling of the heating and cooling systems, thus increasing their efficiency and life.

Table 7. Area of Concrete in $\mathrm{Ft}^{2}$ Required to Store Solar Heat Gain Per $\mathrm{Ft}^{2}$ of South Facing Window

\begin{tabular}{|c|c|c|c|c|}
\hline \multirow{2}{*}{$\begin{array}{l}\text { Allowable } \\
\left.\text { Swing ( }{ }^{\circ} \mathrm{F}\right)\end{array}$} & \multicolumn{4}{|c|}{ Thickness of Concrete } \\
\hline & 2 inch & 4 inch & 8 inch & 12 inch \\
\hline 5 & 50.00 & 25.00 & 12.50 & 8.33 \\
\hline 10 & 25.00 & 12.50 & 6.25 & 4.17 \\
\hline 15 & 16.67 & 8.34 & 4.17 & 2.78 \\
\hline 20 & 12.50 & 6.25 & 3.13 & 2.08 \\
\hline 25 & 10.00 & 5.00 & 2.50 & 1.67 \\
\hline
\end{tabular}




\subsection{Interior Accessories}

The principal advantage of energy-conserving interior accessories is their accessibility and hence, ease of management, as outside conditions change or as the use of the interior changes. Interior accessories such as draperies, roll shades, and venetian blinds are effective in reducing heat gain through windows in the summer as well as reducing heat loss in the winter. The principal disadvantage of interior accessories is the fact that the heat absorbed by the device in reducing heat gain, is partially reradiated into the building interior. In reducing heat loss, the insulative value is minimal if the device does not make a tight seal with the window frame. If the device is potentially effective and is used conscientiously, it can greatly improve the energy performance of the window.

- Because heating loads are the dominant concern in the Mid-Columbia climate, interior accessories that will reduce heat loss are most important. Many commercial products are now available to provide movable insulation for windows. In addition, plans for on-site construction of movable window insulation systems are available from a number of sources, several of which are listed in the bibliography.

A rapidly growing variety of window insulation products is being developed and manufactured. Several manufacturers are marketing window units that have thin venetian blinds sandwiched between panes of glass. These are particularly effective in limiting heat gain but offer limited reduction in heat loss. One window system recently made available has a movable layer of insulation between the glass panes.

In addition to window systems, various types of window shades and shutters are commercially available for addition to a conventional window. Roll down shades are popular because of the convenience of storage when not in use. To be effective at limiting heat loss the shade must have a high R-value and a good seal to the window frame. A quilted material that slides in tracks attached to the window frame offers an R-value of 3.5. Another quite different shade called a "High R" shade has two outer layers of vinyl resembling a conventional shade and three inner aluminized plastic sheets that compress when rolled up and separate into a honeycomb with dead air spaces when rolled down. This shade is bulky and a bit difficult to operate but has an R-value of 10.

Shutter systems can also be used as interior window insulation. One disadvantage of many interior shutter devices is the space required for their operation and storage. Multifold systems are commonly employed to minimize this problem. A vertically rolling shutter of interlocked rigid but hollow PVC slats, which may be operated either manually or automatically to store the shutter above the window, is available. Table 8 lists several currently $\therefore$ marketed items, the approximate R-values, and costs.

Relatively simple and inexpensive plywood shutters with an insulated core of thermax or polyurethane can offer $\mathrm{R}$-values as high as 10 . The key concepts to keep in mind in their design are the need for a tight seal, a high R-value, and easy operation. If constructed of rigid materials, the unit must be easily removed for egress in areas where a fire danger may exist. As a guide for the economic effectiveness of window insulation systems consider that double glazed windows lose approximately 54,000 Btu per heating season per $\mathrm{ft}^{2}$. This is equivalent to $16 \mathrm{kWh}$ or 0.77 therms of natural gas worth 25 and 42 cents per $\mathrm{ft}^{2}$ of window area 
respectively, using the assumed prices in this manual. Having $\mathrm{R}-5$ window insulation in place for $70 \%$ of the heating hours can reduce the loss by $50 \%$. The consistent use of window insulation on the prototype home with double-glazed windows would reduce electricity consumption by $2376 \mathrm{kWh}$, valued at $\$ 37.00$. Although the cost of manufactured devices would probably exceed $\$ 800$, those built on-site could cost less than half of that and prove cost-effective if properly utilized.

Table 8. Currently Available Insulation Devices

\begin{tabular}{|c|c|c|c|}
\hline & & $\begin{array}{c}\text { Approximate } \\
\text { R-Value, } \\
\text { Insulation Alone* } \\
\end{array}$ & $\begin{array}{c}\text { Cost Per Square Foot, } \\
\text { Excluding } \\
\text { Installation } \\
\end{array}$ \\
\hline \multirow[t]{4}{*}{ Interior Insulation } & $\begin{array}{l}\text { Shade } \\
\text { Quilted, } 3 / 8 \text { in. } \\
\text { polyester fiberfill }\end{array}$ & 3.5 & $\$ 4$ \\
\hline & $\begin{array}{l}\text { Layered, aluminized } \\
\text { plastic and vinyl } \\
\text { sheets with dead air spaces }\end{array}$ & 10.0 & 4 \\
\hline & $\begin{array}{l}\text { Folding Shutter } \\
1 \text { in. urethane foam core }\end{array}$ & 7.3 & $5-6$ \\
\hline & $\begin{array}{l}\text { Rolling Shutter } \\
\text { Hollow core PVC slats }\end{array}$ & 3.0 & 5 \\
\hline \multirow[t]{2}{*}{ Exterior Insulation } & Folding Shutter & 7.6 & $8-10$ \\
\hline & $\begin{array}{l}\text { Rolling Shutter } \\
\text { Hollow core PVC slats }\end{array}$ & 2.0 & $10-13$ \\
\hline \multirow[t]{2}{*}{ Intra-Window Insulation } & $\begin{array}{l}\text { High Transmission Film } \\
1 / 2 \text { in. between glazings }\end{array}$ & 1.0 & 1 \\
\hline & $\begin{array}{l}\text { Polystyrene Beads } \\
21 / 2 \text { in. space between glazin }\end{array}$ & ings & $15-20$ \\
\hline
\end{tabular}

*Add 1 if covering a single glazed window, 2 with a double glazed window to estimate overall R-value. 


\subsection{Summary and Prioritization of Conservation Measures}

The conservation measures examined in Section 2.0 are compared in this section to assist in selecting and marketing these features in new homes. To compare the measures some assumptions are made regarding the lifestyle of the occupants, the time horizon of the investment, and present and future economic conditions. Such assumptions are required to project the economic effectiveness of alternative levels of conservation investment and to identify the best combination of options. The effects of various assumed interest and inflation rates are discussed in some detail in Appendix B.

The lifestyle of the building tenants can significantly impact the performance of conservation options, since occupant actions may negate or complement energy conservation potential. For

- instance, if windows and doors are left open during heating periods, the benefit of tripleglazing or storm doors will be offset. Similarly, if the thermost at is set back to $45^{\circ}$ for extended periods, the amount of energy savings attributable to wall and ceiling insulation is reduced. The adoption of the no-cost items identified previously may impact lifestyle to varying degrees. To some, a plain, insulated metal door is so unattractive compared to a carved wooden door that the $\$ 3$ to $\$ 4$ annual energy savings foregone for the wooden door is justified. Those items that necessitate regular action by the occupant (such as window management through the placement of insulating panels, or manual, night thermostat setback) will present varying degrees of inconvenience, depending upon the design of the home and the lifestyle of the occupants. For purposes of subsequent analysis, we make the following assumptions:

1. Occupants will maintain an interior temperature of $70^{\circ}$ in the winter and $78^{\circ}$ in the summer.

2. Windows and doors will be left open only when natural cooling is desirable and can occur.

3. Occupants will accept the insulated door.

4. Occupants do not choose to manually set back their thermostat or manage movable window insulation.

The length of the payback period is particularly important because the effect of the conservation investments on resale value of the home has been ignored. Although it is clear that homes with documented lower fuel bills typically sell for more than otherwise comparable homes, the extent of the effect is left to the individual investor to assess. Since the average duration of occupancy for residential units is seven years and declining, we have assumed that to the average home-buyer, a payback period of five years would be acceptable. Ther efore, a package of conservation options that will result in a five-year payback is identified. Since some

- purchasers may be buying with the intention of staying for extended periods, the effect of incorporating all of the options examined is also discussed.

\section{- 3.1 Prioritization of Conservation Investments}

Because of the increasing cost of new houses, homebuyers must be assured that the additional cost of conservation measures is justified by reduced fuel bills. Several recent surveys 
have found that most homebuyers are willing to spend as much as $\$ 1000$ for additional energy conservation features because of their expectations of increasing energy costs. Manufacturers are responding to this demand by developing and marketing a growing number of energy saving products. The crucial question to the homebuilder or buyer thus becomes, "Which conservation measures should be installed first?"

Obviously, those options with no incremental costs should be incorporated into the homes. These include insulated metal exterior doors, concentration of window area on the south facade, dark exterior colors, and use of fluorescent lighting, task lighting, and daylighting where practicable. In addition, some items have such low incremental cost relative to the ir energy savings that a detailed performance assessment is unnecessary. These include good quality weatherstripping, installation of a continuous vapor barrier and vapor barrier pans, shower flow restrictors, operable windows and framing with thermal breaks. Some of these items may at first require additional effort to locate materials, or properly train contractors; however once the first job has been done subsequent orders and jobs will be simplified.

Since many homebuyers are unaware of the presence or effects of many of the measures, it is good marketing practice to list and document them if possible. With the increasing frequency of utility sponsored building energy audit programs the presence of energy conservation features will become more apparent to first and subsequent buyers.

Beyond the measures that obviously pay for themselves, the selection of options becomes much more complex. Information provided in Appendix B has been used to prepare tables that prioritize the conservation measures according to their cash-flow breakeven periods; that is, the period of time needed for the accumulated value of energy savings to exceed the accumulated costs. From that point on the purchaser "profits" from the investment. It follows then that those items with the shortest breakeven periods represent the best investments.

The items that require actions on the part of the occupants are excluded from this assessment since no assurance exists that homebuyers will want or use such devices. In Table 9 the individual options are listed in order of priority for a home heated with an electric furnace. Table 10 offers similar information for a natural gas heating system and Table 11 for a heat pump system. The incremental costs shown in these tables are net of the cost of the measures which are the starting point for upgrading.

\subsection{General Conclusions}

In the final analysis, an energy-conserving building is a package of interrelated items, not a simple sum of its individual parts. Therefore, the identification of optimal building characteristics will depend largely on the interaction of the building systems, occupants, and environment. We will attempt to identify the optimal mix of conservation measures for a "typical" homebuyer.

In some cases, most notably ceiling insulation, building codes may require the installation of some features that may not appear to be cost-effective. The reasons for this apparent inconsistency may be shortcomings in the regulatory process that do not permit determination of optimal conditions except for broad climatic regions. The reader is cautioned to comply with existing building codes. These requirements may be made cost effective if fuel costs rise more rapidly than assumed in this analysis. 
Table 9. Economic Analysis of Conservation Measures for a Home with an Electric Furnace and Electric Air Conditioning

\begin{tabular}{|c|c|c|c|c|}
\hline 1 & Option & $\begin{array}{c}\text { Incremental } \\
\text { Cost } \\
(1980 \$)\end{array}$ & $\begin{array}{c}\text { Energy } \\
\text { Savings } \\
\text { (kWh Year) }\end{array}$ & $\begin{array}{c}\text { Breakeven } \\
\text { Period } \\
\text { (Years) }\end{array}$ \\
\hline$\because$ & $\begin{array}{l}\text { Insulated Front } \\
\text { Door }\end{array}$ & 0 & 233 & 0 \\
\hline & Natural Venting & 0 & 174 & 0 \\
\hline$\ldots$ & $\begin{array}{r}\text { Night Setback } \\
\text { Thermostat }\end{array}$ & 40 & 1153 & 1 \\
\hline$\ldots$ & $\begin{array}{l}\text { Double to } \\
\text { Triple Glazing }\end{array}$ & 311 & 2997 & 4 \\
\hline$\ldots$ & $\begin{array}{l}\text { R-11 to } R-19 \\
\text { Walls }\end{array}$ & 317 & 3114 & 4 \\
\hline & Storm Door & 120 & 718 & 8 \\
\hline & $\begin{array}{l}\text { R-19 to } R-30 \\
\text { Ceiling }\end{array}$ & 113 & 575 & 9 \\
\hline & $\begin{array}{l}\text { R-30 to } R-38 \\
\text { Ceiling }\end{array}$ & 73 & 235 & $>10$ \\
\hline & $\begin{array}{c}\mathrm{R}-19 \text { to } \mathrm{R}-27 \\
\text { Walls }\end{array}$ & 485 & 939 & $>10$ \\
\hline
\end{tabular}

Table 10. Economic Analysis of Conservation Measures for a Home with a Gas Furnace and Electric Air Conditioning

\begin{tabular}{|c|c|c|c|}
\hline \multirow{2}{*}{$\begin{array}{c}\text { Incremental } \\
\text { Cost } \\
(1980 \$) \\
\end{array}$} & \multicolumn{2}{|c|}{$\begin{array}{l}\text { Energy } \\
\text { Savings }\end{array}$} & \multirow{2}{*}{$\begin{array}{c}\text { Breakeven } \\
\text { Period } \\
\text { (Years) }\end{array}$} \\
\hline & (kWh Year) & (therms) & \\
\hline 0 & 10 & 10 & 0 \\
\hline 0 & 174 & $-\cdots$ & 0 \\
\hline 40 & -- & 56 & 1 \\
\hline 317 & 87 & 148 & 2 \\
\hline 311 & 122 & 142 & 2 \\
\hline 180 & --- & 54 & 3 \\
\hline 120 & 33 & 33 & 4 \\
\hline 113 & 5 & 28 & 4 \\
\hline 73 & 3 & 11 & 8 \\
\hline 485 & 26 & 43 & $>10$ \\
\hline
\end{tabular}


Table 11. Economic Analysis of Conservation Measures for a Home with a Heat Pump

\begin{tabular}{|c|c|c|c|}
\hline Option & $\begin{array}{c}\text { Incremental } \\
\text { Cost } \\
(1980 \$) \\
\end{array}$ & $\begin{array}{l}\text { Energy } \\
\text { Savings } \\
\text { (kWh/yr) }\end{array}$ & $\begin{array}{c}\text { Breakeven } \\
\text { Period }\end{array}$ \\
\hline \multicolumn{4}{|l|}{ Insulated Front } \\
\hline Door & 0 & 142 & 0 \\
\hline Natural Venting & 0 & 174 & 0 \\
\hline \multicolumn{4}{|l|}{ Night Setback } \\
\hline Thermostat & 40 & 679 & 2 \\
\hline $\mathrm{R}-11$ to $\mathrm{R}-19$ Walls & 317 & 1908 & 8 \\
\hline \multicolumn{4}{|l|}{ Double to Triple } \\
\hline Glazing & 311 & 1763 & 9 \\
\hline Storm Door & 120 & 423 & $>10$ \\
\hline \multicolumn{4}{|l|}{$\mathrm{R}-19$ to $\mathrm{R}-30$} \\
\hline Ceiling & 113 & 352 & $>10$ \\
\hline \multicolumn{4}{|l|}{$R-30$ to $R-38$} \\
\hline Ceiling & 73 & 143 & $>10$ \\
\hline $\mathrm{R}-19$ to $\mathrm{R}-27$ Walls & 485 & 553 & $>10$ \\
\hline
\end{tabular}

The options with payback periods of less than five years are grouped into a package termed "intermediate." The measures are assumed to be added to a conventionally built prototype home with R-11 walls, R-19 ceilings, and double glazing. In all cases, the installation of this intermediate package is assumed to result in a $\$ 140$ savings in the cost of the required conditioning systems over the base case. The effects of this package of measures on housing and fuel costs are shown in Table 12.

The estimated first year cost of energy to condition the base case home with an electric furnace and air conditioner is $\$ 245$. By upgrading to $R-19$ wall insulation, triple glazing, and a night setback thermostat at a cost of $\$ 668$ the fuel bills decrease by $44 \%$ to $\$ 138$. This intermediate package, including an insulated door and provision for natural venting, has a net cost of $\mathbf{\$ 5 2 8}$ after credit for system downsizing. Adoption of all the items listed in Table 9 would cost $\$ 1319$ more than the base home. However, the additional expense of $\$ 791$ over the intermediate package brings only $\$ 22$ of additional fuel savings.

If the prototype home is heated with a heat pump system, the first-year conditioning cost is $\$ 149$, a savings of $38 \%$ compared to electric furnace. The intermediate conservation package in this case is a night set back thermostat, insulated door, and natural venting. which costs 
Table 12. Costs for the Prototype House with Various Conditioning Systems Conservation Packages

\begin{tabular}{|c|c|c|c|c|c|}
\hline & $\begin{array}{l}\text { Heating System with Electric } \\
\text { Air Conditioning }\end{array}$ & $\begin{array}{c}\text { Additional(1) } \\
\text { Cost Over } \\
\text { Base Case }\end{array}$ & $\begin{array}{c}\text { Additional(2) } \\
\text { Down Payment }\end{array}$ & $\begin{array}{c}\text { Additional(3) } \\
\text { Mortgage } \\
\text { Payment }\end{array}$ & $\begin{array}{l}\text { First Year( } 4) \\
\text { Energy Cost }\end{array}$ \\
\hline : & $\begin{array}{l}\text { Electric Furnace: } \\
\text { Base House(5) } \\
\text { with Intermediate Package }(6) \\
\text { with All Options }\end{array}$ & $\begin{array}{c}\text { Base Case } \\
\$ 528 \\
\$ 1319\end{array}$ & $\begin{array}{c}\text { Base Case } \\
\$ 106 \\
\$ 263\end{array}$ & $\begin{array}{c}\text { Base Case } \\
\$ 58 \\
\$ 146\end{array}$ & $\begin{array}{l}\$ 245 \\
\$ 138 \\
\$ 116\end{array}$ \\
\hline : & $\begin{array}{l}\text { Electric Heat Pump: } \\
\text { Basic House } \\
\text { with Intermediate Package(6) } \\
\text { with All Options }\end{array}$ & $\begin{array}{l}\$ 1000 \\
\$ 1040 \\
\$ 2319\end{array}$ & $\begin{array}{l}\$ 200 \\
\$ 208 \\
\$ 463\end{array}$ & $\begin{array}{l}\$ 110 \\
\$ 114 \\
\$ 256\end{array}$ & $\begin{array}{l}\$ 149 \\
\$ 117 \\
\$ 73\end{array}$ \\
\hline & $\begin{array}{l}\text { Gas Furnace: } \\
\text { Basic House } \\
\text { with Intermediate Package(6) } \\
\text { with All Options }\end{array}$ & $\begin{array}{l}\$ 300 \\
\$ 1241 \\
\$ 1799\end{array}$ & $\begin{array}{l}\$ 60 \\
\$ 248 \\
\$ 360\end{array}$ & $\begin{array}{l}\$ 33 \\
\$ 136 \\
\$ 198\end{array}$ & $\begin{array}{l}\$ 426 \\
\$ 216 \\
\$ 171\end{array}$ \\
\hline . & $\begin{array}{l}\text { (1) Total Option and heating syst } \\
\text { (2) Down payment of } 20 \% \text { assum } \\
\text { (3) Total increase in annual mort } \\
\text { on monthly payment, divide b } \\
\text { (4) Total first-year energy cost fo } \\
\text { (5) Basic house with R-11 walls, } \\
\text { (6) House with all options having } \\
\text { individual options. }\end{array}$ & $\begin{array}{l}\text { em cost over th } \\
\text { ned. } \\
\text { gage payment; } \\
\text { y } 12 \text {. } \\
\text { r heating and c } \\
\text { R-19 ceilings, } \\
\text { less than five- }\end{array}$ & $\begin{array}{l}\text { base case }(1980 \\
\text { interest rate of } 13 \\
\text { oling the average } \\
\text { louble-glazing, an } \\
\text { ear payback. See }\end{array}$ & $\begin{array}{l}\text { \% assumed. T } \\
\text { euse design. } \\
\text { electric furnac } \\
\text { ables } 9 \text { or } 10\end{array}$ & $\begin{array}{l}\text { Alculate effect } \\
\text { AC. } \\
\text { payback of }\end{array}$ \\
\hline
\end{tabular}

$\$ 40$ and reduces energy costs to $\$ 117$. With all the options in place, the cost increase over the base-case, electric furnace home would be $\$ 2319$, but fuel bills would be only $\$ 73$ per year, a reduction of $70 \%$.

For the home heated with natural gas, a first-year fuel bill of $\$ 426$ is estimated. An intermediate package consisting of $R-30$ ceilings, $R-19$ walls, triple glazing, night set back ther- mostat, storm doors over insulated doors, flue damper, and natural venting would cost an additional $\$ 1081$ and reduce fuel bills by $49 \%$ to $\$ 216$. The savings in the conditioning system make the net cost $\$ 941$. Adding all the options would cost $\$ 1499$ over the gas heated base home and reduce fuel bills to $\$ 171$, a reduction of $60 \%$. 


$\therefore$

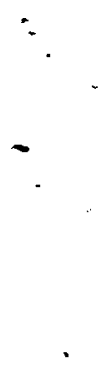




\section{Bibliography}

- The following references are suggested for individuals desiring more detailed information on .... energy conservation strategies. Caution should be exercised in applying strategies recommended in the literature unless their suit ability for this climate is indicated. A recent prolifera* tion of literature has resulted from the demand for energy information, and unfortunately much of it may be dated, misleading, or inaccurate. The references suggested below, however, are considered technically accurate. More complete and continuously updated bibliographies are available free from the following sources:

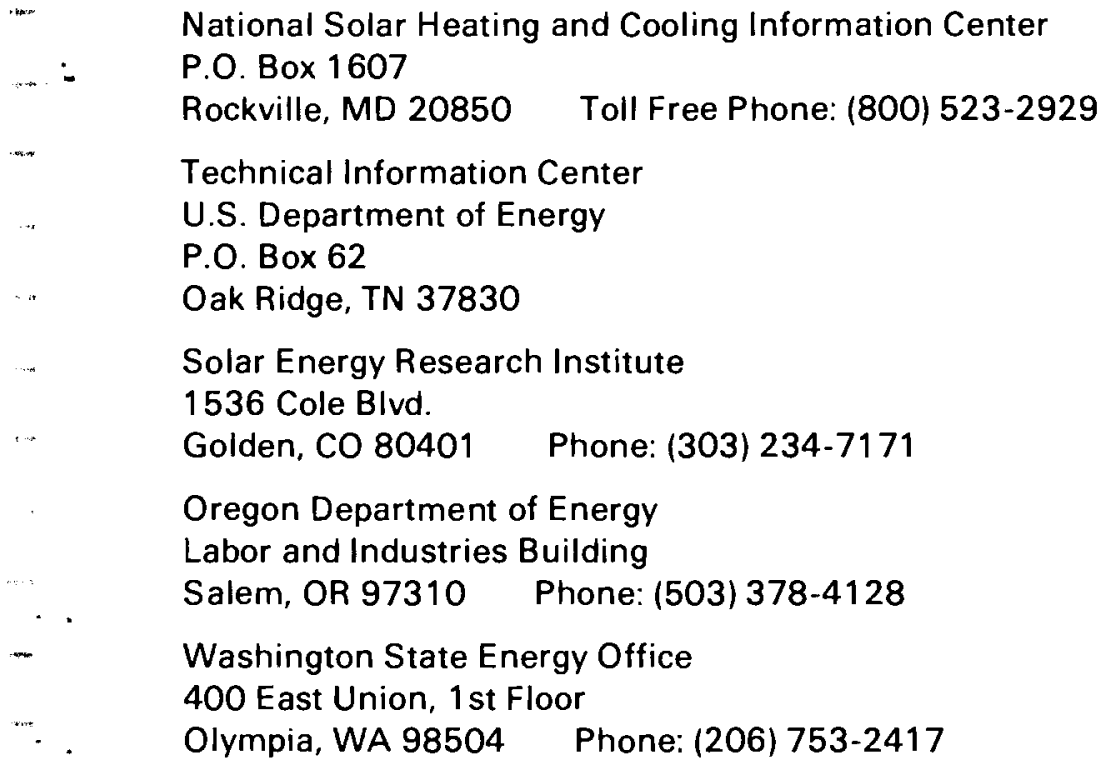

The following references have been reviewed by the authors of this report:

Low-Cost Energy Efficient Shelter for the Owner and Builder.

Eccli, Eugene, Ed. Rodale Press, Emmaus, PA 18049 1976. 408 pp. \$5.95.

Thorough description of specific energy saving, and cost-cutting methods when building or renovating a home. Good articles by experts on financing, codes, construction, insulation, etc.

* Energy and the Builder

$\therefore$

Professional Builder. Cahners Publishing Co. Chicago, IL 60603. 1978. 160 pp. \$15.00. Specific information by builders for builders to improve their understanding of energy flows in the built environment. 


\section{Home Energy How-To}

A. J. Hand. Book Division, Times Mirror Magazines (Popular Science) P.O. Box 2006 Latham, NY 12111.1979. 257 pp. \$9.95.

The book is divided into two parts: ways to conserve energy and ways to produce energy. Over 200 easy-to-follow illustrations and the latest methods and materials make this book one of the best guides for saving energy in the home. Written for the energy-efficiency novice, the book builds from a basic understanding level to the point where the reader can make informed energy conservation decisions.

\section{Window Design Strategies to Conserve Energy}

Robert Hastings and Robert Crenshaw. National Bureau of Standards-Available from the U.S. Government Printing Office Washington, D.C. 20234, Stock number 003-00301794-9. 1977. $\$ 3.75$.

Comprehensive study of the costs and benefits of incorporating window strategies to reduce conditioning requirements. Well researched, thoroughly documented, and conclusive.

\section{Landscaping That Saves Energy Dollars}

Ruth Foster. David Mckay Co. 750 Third Ave. New York, NY 10017. 1978. 184 pp. \$5.95.

A wealth of ideas to keep homes naturally warmer in winter and cooler in summer with "how-to" illustrations throughout. Discusses the theory of the impact of climate on buildings, types and uses of vegetation to provide moderating influences, and facts about trees, shrubs and ground covers.

\section{The Passive Solar Energy Book}

Edward Mazria. Rodale Press Emmaus, PA 18049. 1979. 435 pp. \$12.95.

This book contains all of the information necessary to successfully design an effective passive solar heated building. It is a primer in the fundamental concepts of solar energy and thermal analysis: a source book with descriptions, photographs, illustrations and performance data for many passive solar heated building; and a workbook containing a step-by-step process for designing and sizing passive solar heating systems.

\section{Regional Guidelines for Building Passive Energy Conserving Homes}

AIA Research Corporation. U.S. Government Printing Office, Washington, D.C. 20402. \#621-714/309. 312 pp.

The research and studies forming the basis of this report were conducted by the AlA Research Corporation for the Department of Housing and Urban Development. The book makes specific recommendations of passive energy conserving concepts for each of 16 different climates and suggests appropriate systems for most areas in the United States. 


\section{Money Saving Guide to Energy in the Home}

Consumers Union. Doubleday \& Company, Inc. Garden City, NY 11530. 1978. 102 pp. $\$ 3.50$.

Describes the house as an "energy system," discussing ways and evaluating specific products to reduce infiltration, improve heating system efficiency, keep cool, and save energy in the home's water system. Advice is offered on when to seek professional advice and use programs instituted by the government in response to conservation.

\section{Home Energy for the Eighties}

Ralph Wolfe and Peter Clegg. Garden Way Publishing, Charlotte, VT 05445. 1979. : $\quad 264$ pp. $\$ 10.95$.

The book starts with a discussion of energy conservation in the home and quickly moves to the use of solar, wind, water, and wood technologies in the home. For each energy type the technology is described, economic analyses carried out, and specific recommendations made. Each section includes a catalog of hardware currently available and product comparison charts.

\section{A Design and Construction Handbook for Energy Saving Houses}

Alex Wade. Rodale Press, Emmas, PA. 18049. 373 pp.

This book details the plans of 11 custom-made homes that make use of natural materials and low-cost building techniques that result in low maintenance, low utility bills, and handsome extras seldom found in a ready-to-buy house.

\section{Earth Sheltered Housing Design}

Underground Space Center. University of Minnesota, Minneapolis, MN 55455. 300 pp. $\$ 13.00$.

The "bible" of earth sheltering, this book discusses the costs and benefits of earth sheltered construction and gives specific information on materials, design, and construction. Produced by a university staff, the book is one of the only sources of objective information on the subject. In addition to the books and information sources listed above, several monthly or bimonthly periodicals are available to keep interested persons abreast with the latest information in this rapidly expanding field.

\section{New Shelter}

Rodale Press, 33 East Minor St., Emmaus, PA 18049 (9 issues per year of approx 100 pp. each). $\$ 8.97$.

A reliable and quite comprehensive magazine on ways to make a home more energyefficient. Feature articles include discussions on solar-underground homes, and insulating window devices. Step-by-step instructions and references for further reading are usually provided. 


\section{Solar Age}

SolarVision Inc. P.O. Box 4934, Manchester, NH 03108 (12 issues per year of approx 80 pp. each). $\$ 20.00$.

The official magazine of the American Section of the international Solar Energy Society provides timely and state-of-the-art discussions of the use of solar energy technologies. Each issue focuses upon a specific technology such as solar water heating, earth-sheltered construction, and attached greenhouses. Highly recommended for those interested in solar energy utilization.

\section{Earth Shelter Digest}

WEBCO Publishing. 479 Fort Road, St. Paul, MN 55102 ( 6 issues per year of approx 70 pp. each). $\$ 15.00$.

The magazine provides an accumulation of knowledge and experience in the design and construction of earth-sheltered housing. Photographs and floor plans are provided and builders and buyers are interviewed. Performance data are given when possible, and the rapidly increasing volume of literature in the area is reviewed. 


\section{Appendix A \\ Energy Consumption Calculations}




\section{Appendix A}

\section{Energy Consumption Calculations}

In this section, detailed descriptions of the homes are presented, as well as the sources of information and assumptions used in the energy and economic analysis. The selection of appropriate reference data is of paramount importance, due to the general lack of documented data on the actual results of the conservation measures incorporated in buildings. The major areas of discussion in this section are the house designs and features, selection of appropriate climatic data, infiltration, internal loads, and heating and cooling systems.

\section{A.1 House Design and Features}

A conservation measure analysis was carried out for several residential building designs. The analysis showed that for all of the options considered, there was little variation in energy use on a $\mathrm{Btu} / \mathrm{ft}^{2}$ basis among the designs. From these designs, the one most typical of new construction was selected as a base case. Features of this home include $2 \times 6$ construction on slab, R-11 wall insulation, R-19 ceiling insulation, double-glazing, fireplace and/or woodburning stoves, and central air-conditioning. Two-foot roof overhangs extend around the house unless otherwise noted. This home is $32 \mathrm{ft}$ wide and $38 \mathrm{ft}$ deep and has three bedrooms, two baths, family, living, and dining rooms. The two-story structure has cathedral ceilings and $24 \mathrm{ft}^{2}$ of clerestory windows in front, along with $65 \mathrm{ft}^{2}$ of well-shaded living room windows and a $6 \mathrm{ft}^{2}$ bathroom window. The right side of the house has $37 \mathrm{ft}^{2}$ of glass, the rear has $25 \mathrm{ft}^{2}$ and a $40 \mathrm{ft}^{2}$ patio door, and the left side has $15 \mathrm{ft}^{2}$ of glass, for a total of $212 \mathrm{ft}^{2}$ of glazing. The home has a vestibule (double front) entry adjacent to a $286 \mathrm{ft}^{2}$ garage. The home is depicted in Figure A.1. The ratio of windows to living area is $14.5 \%$.

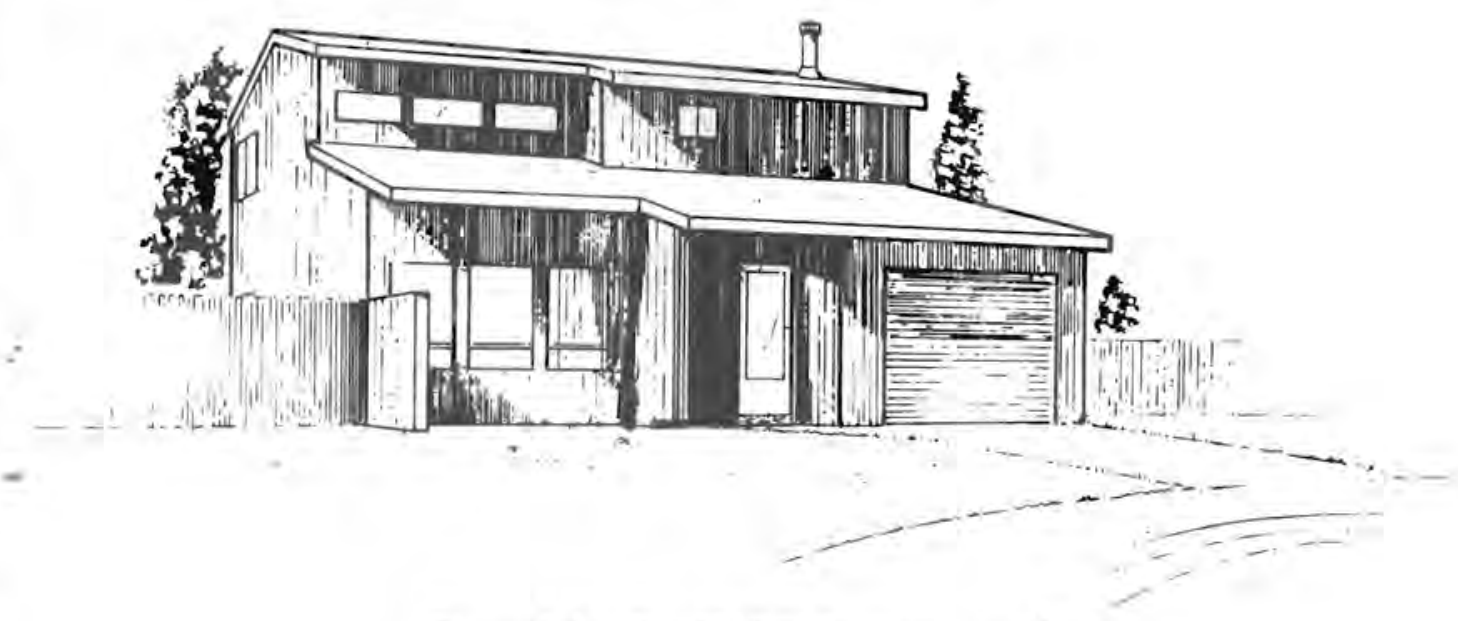

Figure A.1. The $1510 \mathrm{ft}^{2}$ Contemporary Home 


\section{A.2 Climatic Data}

One way to estimate the effectiveness of energy-conserving features when experimental data are unavailable is to evaluate the measures using the best available climatic data and a sophisticated simulation technique. The DOE-2.0A computer model used in this analysis utilizes data regarding the air temperature, ground temperature, humidity, wind speed and direction, cloud cover, precipiation, and solar radiation for every hour of the year. The Hanford Climatological Station, operated by Battelle and located approximately 25 miles north of the Tri-Cities, is the only source of sufficiently complete data in the Columbia Basin to permit accurate utilization of the program. The Battelle measurements have been compared to those taken by the Oregon State University Agricultural Research Center in Hermiston, Oregon, and the Local Climatological Data for Walla Walla and Yakima, Washington. [Average variances rarely exceed $10 \%$ so the climatic data are generally applicable to the Mid-Columbia area depicted in Figure 1.] Buildings in non-standard locations, such as adjacent to bodies of water or tall buildings, on protected hillsides, or well-shaded by trees, may have microclimates significantly different from the climatic data used in these analyses. Although DOE-2.OA is capable of considering some of these variations, detailed analysis of various microclimates was not undertaken.

\section{A.3 Infiltration Rate Estimation}

Air leakage through the building envelope, called infiltration, constitutes from $50-70 \%$ of the heating and cooling requirements for a well-insulated home. Unfortunately, it is difficult to characterize, since air may move through or around open or closed doors and windows, electrical boxes, cracks in the walls and ceilings, and between the sill plate and the foundation.

Because the infiltration rate is a function of wind speed and indoor and outdoor temperatures, an hourly calculation is necessary for accuracy. The DOE 2.OA computer model accounts for these factors.

The model uses a Coblentz-Achenbach equation with coefficients supplied by the National Bureau of Standards (NBS). The formula is given by:

$$
A C=0.252+0.0218 \mathrm{~V}+0.0084\left(T_{a}-T_{r}\right)
$$

where

$$
\begin{aligned}
& A c=\text { the air exchange rate in air changes per hour } \\
& V=\text { the wind speed in miles per hour } \\
& T_{a}=\text { the ambient air temperature }\left({ }^{\circ} \mathrm{F}\right) \\
& T_{r}=\text { the room temperature }\left({ }^{\circ} \mathrm{F}\right)
\end{aligned}
$$

This equation, which is linear in wind speed and temperature differential, reproduces observed results of several major experiments and is the most accurate and realistic model available. It estimates an average of 0.6 air changes per hour for U.S. climates, which is 
consistent with the mean of over 50 experiments on infiltration. It is normalized to measurements on the Bowman house on the NBS campus. For that house, it predicts one air change per hour under winter design conditions, which corresponds to measured results. This formula is used for all sizes of houses in all climates. We would, however, expect two-story houses to have somewhat higher infiltration rates due to the greater temperature differential within the structure and because wind speeds are higher at greater distances above the ground.

\section{. A.4 Internal Loads}

Since houses are built to be occupied, they are best modeled that way. Normal occupancy will

- involve the release of heat to the room by people, appliances, and lighting. This heat, or internal load, will affect the heating and cooling loads imposed upon the conditioning system. Since the internal loads will tend to reduce heating loads while increasing cooling loads, their characterization is important when optimizing the conservation measures to be employed.

The average contributions to internal loads from various sources are shown in Table A.1. Appliance loads are predicted based on efficiencies expected in 1981 models. As the table indicates, water heating, lighting, refrigeration, cooking, and body heat contribute the major share of internal loads. The estimate of internal loads is probably accurate to with in $\pm 20 \%$ for most homes. The internal loads are a property of family characteristics and hence are assumed to be independent of house size (except for lighting, which is assumed to increase proportionally to floor area). This is due to the fact that variations in appliance ownership, and habits of their users cannot be correlated to house size.

- Since the magnitude of internal loads varies throughout the day, and the computer calculates energy requirements on an hourly basis, it was necessary to develop a representative hourly profile of internal loads. Internal load schedules developed in previous modeling efforts were used to develop a load schedule for the base case house (Table A.2). The schedule shows the expected daily pattern of peaks at breakfast and dinner time, greater loads in the evening and mid-day, and lowest loads in the early morning. Seasonal variations were not explicitly considered because their effects are so small.

For the $1510 \mathrm{ft}^{2}$ base case home it was found that on the winter design day, internal loads decreased heating loads by $7.8 \%$ and that on the summer design day, they increased cooling loads by $17.5 \%$. As the building becomes increasingly energy-efficient these percentages increase. In low-energy houses constructed in Canada, internal loads supply nearly twothirds of the heating load in a climate with over 11,000 heating degree days.

$\therefore$ The builder exercises little control over the internal loads other than in the placement of the water heater (whether in the conditioned zone or not) and in the installation of devices to allow recirculation or exhaustion of heat from internal load sources. Examples of these are adjustable louvers on electric dryer exhaust connections and exhaust hoods over stoves. In this region it is recommended that the water heater be located in the conditioned zone since heating needs predominate, and that caution be exercised to not oversize exhaust fans, which remove heat unnecessarily. Two speed exhaust fans are recommended so that the appropriate exhaust rate can be selected, based upon the interior conditions. 
Table A.1. Estimated Average Internal Loads

\begin{tabular}{|c|c|c|c|c|}
\hline $\begin{array}{c}\text { Source of } \\
\text { Internal Loads }\end{array}$ & Saturation & Energy per Unit & $\begin{array}{l}\text { Percent } \\
\text { Indoor }\end{array}$ & $\begin{array}{l}\text { Sensible } \\
\text { Heat Load }\end{array}$ \\
\hline New Refrigerator & 1.00 & $1,125 \mathrm{kWh} / \mathrm{yr}$ & 100 & $1.125 \mathrm{kWh} / \mathrm{hr}$ \\
\hline Old Refrigerator & 0.15 & $600 \mathrm{kWh} / \mathrm{yr}$ & 50 & $45 \mathrm{kWh} / \mathrm{yr}$ \\
\hline Range (cooking) & 1.00 & $\begin{array}{l}60 \text { therms } / y r \\
\text { or } \\
1,200 \mathrm{kWh} / \mathrm{yr}\end{array}$ & 100 & $800 \mathrm{kWh} / \mathrm{yr}$ \\
\hline Freezer & 0.45 & $950 \mathrm{kWh} / \mathrm{yr}$ & 50 & $214 \mathrm{kWh} / \mathrm{yr}$ \\
\hline Lighting & 1.00 & $1,150 \mathrm{kWh} / \mathrm{yr}$ & 90 & $1,038 \mathrm{kWh} / \mathrm{yr}$ \\
\hline Water Heater & 1.00 & $\begin{array}{c}200 \text { therms/yr } \\
\text { or } \\
3,400 \mathrm{kWh} / \mathrm{yr}\end{array}$ & 28 & $940 \mathrm{kWh} / \mathrm{yr}$ \\
\hline Television & 2000 set $h r / y r$ & $200 \mathrm{kWh} / \mathrm{yr}$ & 100 & $200 \mathrm{kWh} / \mathrm{yr}$ \\
\hline Clothes Dryer & 0.60 & $900 \mathrm{kWh} / \mathrm{yr}$ & 17 & $90 \mathrm{kWh} / \mathrm{yr}$ \\
\hline Dishwasher & 0.70 & $250 \mathrm{kWh} / \mathrm{yr}$ & 100 & $175 \mathrm{kWh} / \mathrm{yr}$ \\
\hline Misc. Appliances & & & & $125 \mathrm{kWh} / \mathrm{yr}$ \\
\hline People & $3.2 /$ household & & & $930 \mathrm{kWh} / \mathrm{yr}$ \\
\hline Total & & & & $\begin{array}{c}5,680 \mathrm{kWh} / \mathrm{yr} \\
\text { or } \\
53,100 \mathrm{Btu} / \mathrm{day}\end{array}$ \\
\hline
\end{tabular}

Table A.2. Internal Load Schedule for Prototype House

\begin{tabular}{|c|c|c|c|}
\hline Hour & $\begin{array}{c}\text { Load } \\
\text { (Btu/hr) }\end{array}$ & Hour & $\begin{array}{c}\text { Load } \\
\text { (Btu/hr) }\end{array}$ \\
\hline 1 & 1,078 & 13 & 1,616 \\
\hline 2 & 1,078 & 14 & 1,348 \\
\hline 3 & 1.078 & 15 & 1,401 \\
\hline 4 & 1,078 & 16 & 1,401 \\
\hline 5 & 1,078 & 17 & 2,048 \\
\hline 6 & 1.801 & 18 & 2,209 \\
\hline 7 & 2,263 & 19 & 2,371 \\
\hline 8 & 4,526 & 20 & 3,718 \\
\hline 9 & 2,641 & 21 & 3,718 \\
\hline 10 & 1,616 & 22 & 3,880 \\
\hline 11 & 1,616 & 23 & 3,880 \\
\hline 12 & 2,155 & 24 & 3,503 \\
\hline
\end{tabular}




\section{A.5 Heating and Cooling Systems}

Heating and cooling system performance characteristics affect fuel savings because an efficient system requires less fuel regardless of the thermal characteristics of the building shell.

The efficiency of a central air-conditioner depends primarily upon the outdoor temperature when cooling is required, the matching of system size to load, and the relative humidity of the air to be conditioned. The efficiency is rated, using a COP or an EER. EERs vary from 6 to 11.6

- and corresponding COPs from 1.76 to 3.40 , the higher figures representing more efficient and usually higher-priced equipment. An average annual COP of 2.3 is assumed, in this analysis. corresponding to an EER of 7.0.

Heat pump, electric furnace, and gas furnace heating systems were analyzed. The electric furnace is assumed to have an efficiency of $100 \%$ or a COP of 1.0 . Thus, the forced air ducting is assumed to be either in the living space or is very well-insulated. A gas furnace is assumed to cost $\$ 300$ more than the electric furnace and operate at $70 \%$ efficiency. The reduced efficiency is due to heat loss to the outside through the flue. The performance of the heat pump is a function of the same factors affecting the air-conditioner. Due to lack of experimental data and capability for doing an hourly simulation of heat pump performance, an average annual COP of 1.7 is assumed (Briggs and Shaffer 1977), corresponding to an efficiency of $170 \%$. 
:

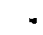

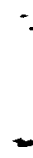
- 
Appendix B

Economic Analyses of Energy

Conservation Options 


\section{Appendix B}

\section{Economic Analyses of Energy Conservation Options}

\section{B.1 Economic Assumptions}

The expected energy savings for various conservation options, estimated using DOE-2, have been combined with cost data and economic assumptions to analyze the economics of each option. These analyses compare the monetary costs of conserving energy with monetary savings over the life of the conservation options.

To estimate the costs of the various conservation devices (in 1980 dollars), home buyers' purchase prices were estimated by a local builder for most of the options. Costs for other options were calculated from the Sears Catalog, Means' Construction Cost Data, and Consumer Reports buying guide.

The cost of the conservation options was assumed to be added to the purchase price of the basic house. To be consistent with current economic conditions, it was assumed that the home-buyers would make a down payment of $20 \%$ on the house and would pay the rest with a 30 -year mortgage at $13.5 \%$ interest. Therefore, purchase of a conservation option would result in both an increased down payment and a larger monthly mortgage payment.

The addition of a conservation option to a house would affect the home-buyer's income and property taxes. Income taxes would be affected because interest payments are deductible. Thus, the homeowner will save an amount equal to the portion of the increased mortgage payments, that is, interest, times his/her income tax rate. For the purpose of this analysis, it was assumed that the home-buyers are in the $25 \%$ tax bracket. Because the addition of a conservation option would increase the value of the house, property taxes for the house would be increased. In this analysis, a property tax rate of 21 mills, which corresponds to the rate in Hermiston, Oregon, was used.

To calculate the monetary savings that occur over time due to installation of an energy conservation option, projection of energy prices was necessary. Corresponding to April 1980 energy prices in Hermiston, electricity was assumed to cost $1.54 \mathrm{C}$ per $\mathrm{kWh}$ and natural gas $55 \mathrm{c}$ per therm. This analysis assumed a $5 \%$ real rate of inflation for electricity and an $8 \%$ real rate for natural gas, both of which represent price trends in the recent past. A "real inflation rate" represents the rate of price escalation above that due to general inflation. General inflation was assumed to be $10 \%$ per year. The price trends used are much more likely to be accurate in the near future than in 10 to 20 years.

Using the above assumptions for each conservation option, the total annual monetary savings are calculated as the sum of the energy cost savings and additional tax deductions for interest - payments. Energy price escalation will increase these savings over time. The total annual cost of the option is computed as the sum of the additional mortgage payment and property taxes and includes the down payment. Although costs are subtracted from savings for each year to yield net annual savings, because of general inflation, the buying power of dollars is not 
constant. To convert dollars in any future year to present year dollars, they must be multiplied by a factor $1 /(1+i) n$, where $i$ is the rate of general inflation and $n$ is the year $(1980=$ year 0$)$. Once the net annual savings have been converted to 1980 dollars, they are summed to show cumulative savings from year zero to any given year. The length of time until the cumulative savings become positive (that is, total savings exceed total costs in 1980 dollars) is defined as the "breakeven point." The breakeven point is not equivalent to the simple payback (cost/annual savings) due to the escalation of fuel prices.

The calculation of payback periods in this analysis does not consider the time value of money or the effect of conservation investment on resale value. Even without price inflation, a dollar today is worth more to most people than a dollar a year from now because the dollar today could be invested at some rate of return. For example, if the dollar were placed in the bank at $5 \%$, it would be worth $\$ 1.05$ next year. Because people are all so different, a single rate of return that reflects people's preference for money now rather than later is difficult to establish. Similarly, the value of a conservation measure to future buyers, which would be reflected in the resale value of the house, cannot be characterized accurately. Therefore, it was assumed that the lost opportunity to otherwise utilize the money invested in conservation is offset by the resultant gain in the resale value of the property.

The following assumptions have been used consistently throughout the economic analyses.

- The cost of conservation options is included in the home mortgage. The buyer makes a $20 \%$ down payment in year zero (i.e., at time of purchase) and pays the remainder with a 30 -year mortgage at $13.5 \%$ interest.

- General inflation is $10 \%$ per year.

- Electricity prices are $1.54 \mathrm{c}$ per $\mathrm{kWh}$ and escalate at $15 \%$ per year (i.e., $5 \%$ real plus $10 \%$ general inflation).

- Natural gas prices are $55 \%$ per therm and escalate at $18 \%$ per year (i.e., $8 \%$ real plus $10 \%$ general inflation).

- The property tax rate is 21 mills and no reassessments occur.

- Homeowners are in the $25 \%$ tax bracket.

\section{B.2 Sensitivity Analysis}

The cash flow analyses are potentially useful in evaluating the cost-effectiveness of the various energy conservation options. However, this information should be carefully interpreted. First, as mentioned earlier, there is approximately a $\pm 10 \%$ error in the estimates of the energy savings from the conservation options. Depending upon occupants' life-styles and prevailing weather conditions, the actual variation in energy consumption among households may be even greater. Second, this analysis depends on economic assumptions that may or may not reflect actual future conditions. To demonstrate the effects that these variations in assumptions could have on the outcome of this analysis, the calculations for one conservation option have been repeated using different values for the major variables. The results of these calculations are presented in Table B.1. The "base case" in the first column shows the 
Table B.1. Net Annual Savings from Installing a Storm Door in a Natural Gas-Heated House (in constant 1980 dollars)

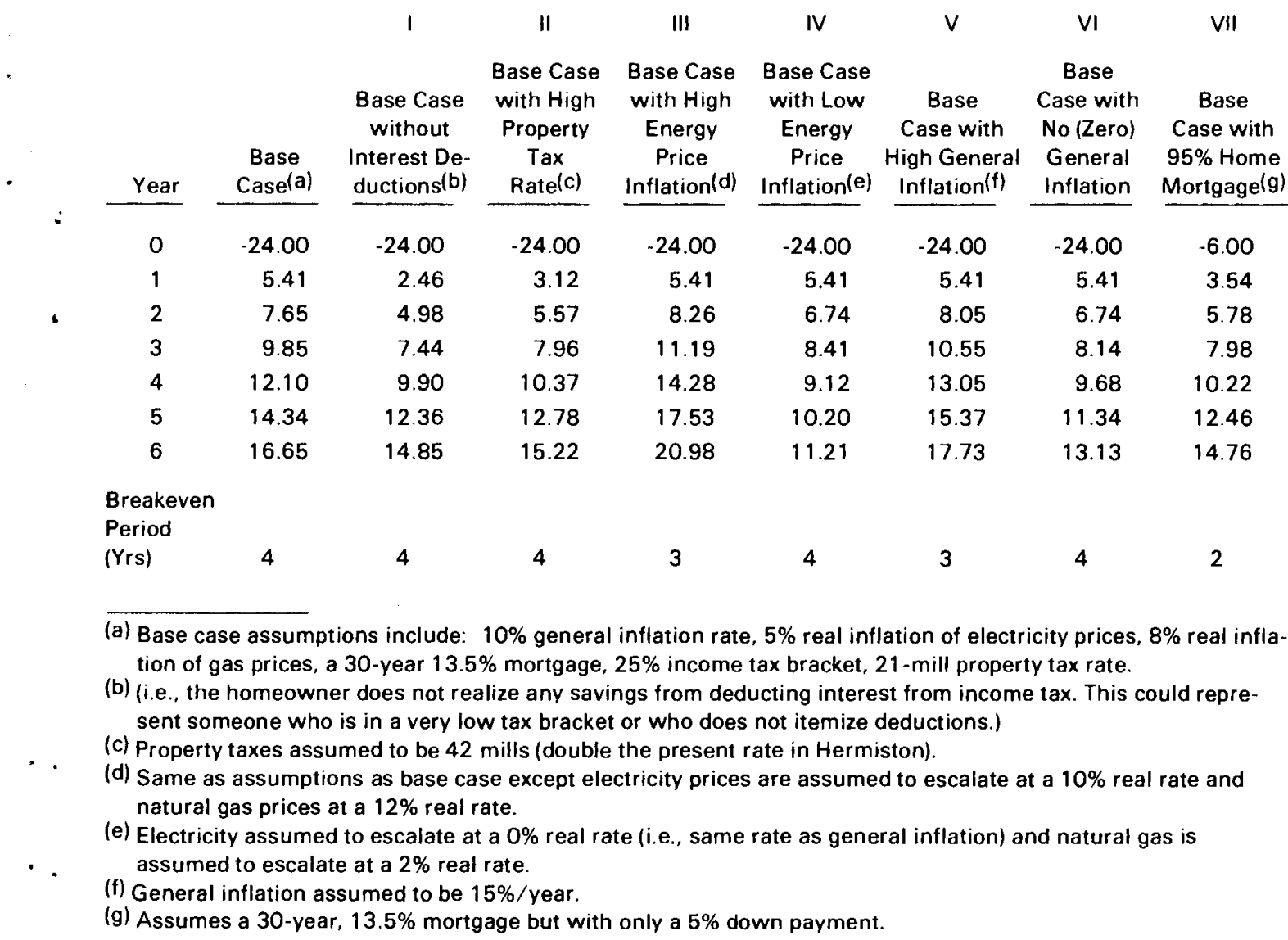

expected net annual savings in 1980 dollars, using the previously discussed economic assumptions from installation of a storm door in a house with a natural gas furnace and electric air-conditioner. Each of the other columns shows this same cash flow with a single assumption altered each time. Columns I and II show that lower tax brackets or higher $\therefore$ property taxes decrease the expected monetary savings from conservation. However, because the tax rates are not major factors in the analyses, their effects on the option's costeffectiveness are small.

- The rate of energy price inflation has a larger effect on overall conservation economics. The third column of Table B. 1 shows that assuming very high inflation rates in energy prices (10 and $12 \%$ real escalation rates, respectively, for electricity and gas) actually reduces the breakeven period from four to three years. Low inflation rates $(0$ and $2 \%$ real rates, respectively, for electricity and gas) increase the payback period and significantly decrease overall 
monetary savings (Column IV). Because fuel price inflation rates are compounded over time, the longer an option's payback period, the more sensitive it will be to the assumed inflation rate in energy prices. In columns $V$ and VI, however, it can be seen that the overall results of the economic analysis change little under assumed general inflation rates of 0 to $15 \%$ annually.

The last column shows the cash flow when the storm door is installed in a house that is purchased with a $95 \%$ loan. This means that the down payment is decreased considerably, while the mortgage payments are increased. By delaying some of the payments for the energy conservation option into the future, while still realizing energy cost savings on an annual basis, the homeowner recoups the initial outlay more rapidly. In this case, the payback period is shortened to 1.6 years. In general, the smaller the percentage down payment, the shorter the payback period will be.

\section{B.3 Cash Flow Analyses}

In the cash flow analyses that follow, negative signs (-) represent cash outlays by the homeowner. Positive numbers (no sign) represent savings to the homeowner.

\section{B.3.1 Analysis for Option of Increasing Wall Insulation From R-11 to R-19}

As wall insulation is increased from R-11 to R-19, the total effective R-value of the walls increases from R-12.5 to R-20.5. This can be accomplished most economically by adding 3 in. (for a total of 6 in.) of fiberglass batt insulation in $2 \times 6$ frame construction. A unit cost of $14.0 \mathrm{C} / \mathrm{ft}^{2}$ of net wall area is used to calculate the additional cost for this option of $\$ 317.00$. The additional insulation reduces annual heating loads by 10.3 million $B t u(27 \%)$ and cooling loads by 0.70 million Btu (10\%).

\begin{tabular}{|c|c|c|c|c|c|c|c|}
\hline \multirow[b]{2}{*}{ Year } & \multicolumn{7}{|c|}{ Cash Flow for a Home with an Electric Furnace } \\
\hline & $\begin{array}{c}\text { Additional } \\
\text { Mortgage } \\
\text { Payment } \\
(\$ / y r) \\
\end{array}$ & $\begin{array}{c}\text { Annual } \\
\text { Electricity } \\
\text { Cost } \\
\text { Savings } \\
(\$ / y r) \\
\end{array}$ & $\begin{array}{c}\text { Additional } \\
\text { Property } \\
\text { Taxes } \\
(\$ / y r) \\
\end{array}$ & $\begin{array}{c}\text { Interest } \\
\text { Tax } \\
\text { Deductions } \\
\text { (s/yr) } \\
\end{array}$ & $\begin{array}{c}\text { Net } \\
\text { Annual } \\
\text { Savings } \\
(\$ / y r)\end{array}$ & $\begin{array}{c}\text { Net } \\
\text { Annual } \\
\text { Savings } \\
(1980 \text { s) } \\
\end{array}$ & $\begin{array}{c}\text { Net } \\
\text { Cumulative } \\
\text { Savings } \\
(1980 \mathrm{~s}) \\
\end{array}$ \\
\hline 0 & -63.40 & 0 & 0 & 0 & -63.40 & -63.40 & -63.40 \\
\hline 1 & -34.86 & 47.96 & -6.66 & 8.55 & 14.99 & 13.63 & -49.77 \\
\hline 2 & -34.86 & 55.15 & -6.66 & 8.53 & 22.16 & 18.31 & -31.46 \\
\hline 3 & -34.86 & 63.42 & -6.66 & 8.51 & 30.41 & 22.85 & -8.61 \\
\hline 4 & -34.86 & 72.93 & -6.66 & 8.48 & 39.89 & 27.25 & 18.64 \\
\hline 5 & -34.86 & 83.87 & -6.66 & 8.45 & 50.80 & 31.54 & 50.18 \\
\hline 6 & -34.86 & 96.46 & -6.66 & 8.41 & 63.35 & 35.76 & 85.94 \\
\hline
\end{tabular}

Electricity consumption is reduced by $3,114 \mathrm{kWh}$ annually and the cash flow break even point is reached in less than four years. 
Cash Flow for a Home with a Gas Furnace

\begin{tabular}{|c|c|c|c|c|c|c|c|c|c|}
\hline & Year & $\begin{array}{c}\text { Added } \\
\text { Mortgage } \\
\text { Payment } \\
(\$ / y r)\end{array}$ & $\begin{array}{c}\text { Annual } \\
\text { Electric } \\
\text { Cost } \\
\text { Savings } \\
(\$ / y r)\end{array}$ & $\begin{array}{c}\text { Natural } \\
\text { Gas } \\
\text { Savings } \\
(\$ / y r)\end{array}$ & $\begin{array}{l}\text { Added } \\
\text { Property } \\
\text { Taxes } \\
(\$ / y r)\end{array}$ & $\begin{array}{c}\text { Interest } \\
\text { Tax } \\
\text { Deductions } \\
(\mathbf{s} / \mathrm{y} r)\end{array}$ & $\begin{array}{c}\text { Net } \\
\text { Annual } \\
\text { Savings } \\
(\$ / y r) \\
\end{array}$ & $\begin{array}{c}\text { Net } \\
\text { Annual } \\
\text { Savings } \\
(1980 \$) \\
\end{array}$ & $\begin{array}{c}\text { Net } \\
\text { Cumulative } \\
\text { Savings } \\
(1980 \text { \$) } \\
\end{array}$ \\
\hline & 0 & -63.40 & 0 & 0 & 0 & 0 & -63.40 & -63.40 & -63.40 \\
\hline & 1 & -34.86 & 1.34 & 81.17 & -6.66 & 8.55 & 44.49 & 44.99 & -18.41 \\
\hline & 2 & -34.86 & 1.54 & 95.78 & -6.66 & 8.53 & 64.33 & 53.17 & 34.76 \\
\hline \multirow[t]{2}{*}{$:$} & 3 & -34.86 & 1.77 & 113.02 & -6.66 & 8.51 & 81.78 & 61.44 & 96.20 \\
\hline & 4 & -34.86 & 2.04 & 133.36 & -6.66 & 8.48 & 102.36 & 69.91 & 166.11 \\
\hline
\end{tabular}

Electricity consumption is reduced by $87 \mathrm{kWh}$ and natural gas consumption by 148 therms annually. The breakeven point is reached in less than 2 years.

\begin{tabular}{|c|c|c|c|c|c|c|c|}
\hline \multicolumn{8}{|c|}{ Cash Flow for a Home with a Heat Pump } \\
\hline Year & $\begin{array}{c}\text { Added } \\
\text { Mortgage } \\
\text { Payment } \\
(\$ / y r)\end{array}$ & $\begin{array}{c}\text { Annual } \\
\text { Electric } \\
\text { Cost } \\
\text { Savings } \\
(\$ / y r)\end{array}$ & $\begin{array}{l}\text { Added } \\
\text { Property } \\
\text { Taxes } \\
(\$ / y r)\end{array}$ & $\begin{array}{c}\text { Interest } \\
\text { Tax } \\
\text { Deductions } \\
(\$ / y r)\end{array}$ & $\begin{array}{c}\text { Net } \\
\text { Annual } \\
\text { Savings } \\
\text { (\$/yr) }\end{array}$ & $\begin{array}{c}\text { Net } \\
\text { Annual } \\
\text { Savings } \\
\text { (1980 \$) }\end{array}$ & $\begin{array}{c}\text { Net } \\
\text { Cumulative } \\
\text { Savings } \\
(1980 \text { \$) }\end{array}$ \\
\hline 0 & -63.40 & 0 & 0 & 0 & -63.40 & -63.40 & -63.40 \\
\hline 1 & -34.86 & 29.38 & -6.66 & 8.55 & -3.59 & -3.26 & -66.66 \\
\hline 2 & -34.86 & 33.79 & -6.66 & 8.53 & 0.80 & 0.66 & -66.66 \\
\hline 3 & -34.86 & 38.86 & -6.66 & 8.51 & 5.85 & 4.40 & .61 .60 \\
\hline 4 & -34.86 & 44.69 & -6.66 & 8.48 & 11.65 & 7.96 & -53.64 \\
\hline 5 & -34.86 & 51.39 & -6.66 & 8.45 & 18.32 & 11.38 & -42.26 \\
\hline 6 & -34.86 & 59.10 & -6.66 & 8.41 & 25.99 & 14.67 & -27.59 \\
\hline 7 & -34.86 & 67.96 & -6.66 & 8.37 & 34.81 & 17.86 & -9.73 \\
\hline 8 & -34.86 & 78.15 & -6.66 & 8.32 & 44.95 & 20.87 & 11.24 \\
\hline 9 & -34.86 & 84.88 & -6.66 & 8.26 & 56.62 & 24.01 & 35.25 \\
\hline
\end{tabular}

Electricity consumption is reduced by $1908 \mathrm{kWh}$ and the breakeven point is reached in 8 years.

\section{B.3.2 Analysis for Option of Increasing Wall Insulation from R-19 to R-27}

$\therefore$ As wall insulation is increased from R-19 to R-27, there is an increase in the total effective $R$ value from R-20.5 to R-28.5. This is most economically accomplished by adding insulative

- sheathing or $1 \mathrm{in}$. of polyurethane board over $2 \times 6$ stud framing with 6 in. of insulation. A unit cost of $27 \mathrm{c} / \mathrm{ft}^{2}$ of net wall area was used to calculate the total additional cost for the option of $\$ 485.00$. The additional insulation reduces annual heating and cooling loads by 3.1 million Btu $(8 \%)$ and 0.2 million Btu (3\%) respectively. 


\begin{tabular}{|c|c|c|c|c|c|c|c|}
\hline \multirow[b]{2}{*}{ Year } & \multicolumn{6}{|c|}{ Cash Flow for a Home with an Electric Furnace } & \multirow[b]{2}{*}{$\begin{array}{c}\text { Net } \\
\text { Cumulative } \\
\text { Savings } \\
(1980 \$)\end{array}$} \\
\hline & $\begin{array}{c}\text { Added } \\
\text { Mortgage } \\
\text { Payment } \\
(\$ / y r)\end{array}$ & $\begin{array}{c}\text { Annual } \\
\text { Electric } \\
\text { Cost } \\
\text { Savings } \\
(\$ / y r)\end{array}$ & $\begin{array}{l}\text { Added } \\
\text { Property } \\
\text { Taxes } \\
(\$ / y r) \\
\end{array}$ & $\begin{array}{c}\text { Interest } \\
\text { Tax } \\
\text { Deductions } \\
(\$ / y r)\end{array}$ & $\begin{array}{c}\text { Net } \\
\text { Annual } \\
\text { Savings } \\
(\$ / y r)\end{array}$ & $\begin{array}{c}\text { Net } \\
\text { Annual } \\
\text { Savings } \\
(1980 \$)\end{array}$ & \\
\hline 0 & -97.00 & 0 & 0 & 0 & -97.00 & -97.00 & -97.00 \\
\hline 1 & -53.33 & 14.46 & -10.19 & 13.08 & -37.98 & -34.53 & -131.53 \\
\hline 2 & -53.33 & 16.63 & -10.19 & 13.05 & -35.84 & -29.62 & -161.15 \\
\hline 3 & -53.33 & 19.12 & -10.19 & 13.01 & -33.32 & -25.03 & -186.18 \\
\hline 4 & -53.33 & 21.99 & -10.19 & 12.96 & -30.57 & -20.88 & -207.06 \\
\hline 5 & -53.33 & 25.29 & -10.19 & 12.91 & -27.32 & -16.96 & -224.02 \\
\hline 6 & -53.33 & 29.08 & -10.19 & 12.85 & -23.59 & -13.32 & -237.34 \\
\hline 7 & -53.33 & 33.45 & -10.19 & 12.78 & -19.29 & -9.90 & -247.24 \\
\hline 8 & -53.33 & 38.46 & -10.19 & 12.71 & -14.35 & -6.69 & -253.93 \\
\hline 9 & -53.33 & 44.23 & -10.19 & 12.62 & -8.67 & -3.68 & -257.61 \\
\hline 10 & -53.33 & 50.87 & -10.19 & 12.52 & -2.13 & -0.82 & -258.43 \\
\hline
\end{tabular}

While electricity consumption is reduced by $939 \mathrm{kWh}$, the breakeven point may not even be reached after 20 years.

\begin{tabular}{|c|c|c|c|c|c|c|c|c|}
\hline \multirow[b]{2}{*}{ Year } & \multicolumn{7}{|c|}{ Cash Flow for a Home with a Gas Furnace } & \multirow[b]{2}{*}{$\begin{array}{c}\text { Net } \\
\text { Cumulative } \\
\text { Savings } \\
(1980 \text { \$) } \\
\end{array}$} \\
\hline & $\begin{array}{c}\text { Added } \\
\text { Mortgage } \\
\text { Payment } \\
(\$ / y r) \\
\end{array}$ & $\begin{array}{c}\text { Annual } \\
\text { Electric } \\
\text { Cost } \\
\text { Savings } \\
(\$ / y r)\end{array}$ & $\begin{array}{c}\text { Natural } \\
\text { Gas } \\
\text { Cost } \\
\text { Savings } \\
(\$ / y r)\end{array}$ & $\begin{array}{c}\text { Added } \\
\text { Property } \\
\text { Taxes } \\
(\$ / y r) \\
\end{array}$ & $\begin{array}{c}\text { Interest } \\
\text { Tax } \\
\text { Deductions } \\
(\$ / y r) \\
\end{array}$ & $\begin{array}{c}\text { Net } \\
\text { Annual } \\
\text { Savings } \\
(\$ / y r)\end{array}$ & $\begin{array}{c}\text { Net } \\
\text { Annual } \\
\text { Savings } \\
(1980 \$) \\
\end{array}$ & \\
\hline 0 & .97 .00 & 0 & 0 & 0 & 0 & -97.00 & -97.00 & -97.00 \\
\hline 1 & -53.33 & 0.40 & 23.87 & -10.19 & 13.08 & -26.17 & -23.79 & -120.79 \\
\hline 2 & -53.33 & 0.46 & 28.17 & -10.19 & 13.05 & -21.84 & -18.05 & -138.84 \\
\hline 3 & -53.33 & 0.53 & 33.24 & -10.19 & 13.01 & -16.74 & -12.58 & -151.42 \\
\hline 4 & -53.33 & 0.61 & 39.22 & -10.19 & 12.96 & -10.73 & -7.33 & -158.75 \\
\hline 5 & -53.33 & 0.70 & 46.28 & -10.19 & 12.91 & -3.63 & -2.25 & -161.00 \\
\hline 6 & -53.33 & 0.80 & 54.61 & -10.19 & 12.85 & 4.74 & 2.68 & -158.32 \\
\hline 7 & -53.33 & 0.93 & 64.44 & -10.19 & 12.78 & 14.63 & 7.51 & -150.81 \\
\hline 8 & -53.33 & 1.06 & 76.04 & -10.19 & 12.71 & 26.29 & 12.26 & -138.55 \\
\hline 9 & -53.33 & 1.22 & 89.72 & -10.19 & 12.62 & 40.04 & 16.98 & -121.57 \\
\hline 10 & -53.33 & 1.41 & 105.87 & -10.19 & 12.52 & 56.28 & 21.70 & -99.87 \\
\hline
\end{tabular}

Electricity consumption is reduced by $26 \mathrm{kWh}$ and gas consumption by 43 therms, but the breakeven point is not reached after 10 years.

\section{Cash Flow for a Home with a Heat Pump}

Since electricity consumption is only reduced by $553 \mathrm{kWh}$, the cash flow is even less favorable than in the electric and gas furnace cases. 


\section{B.3.3 Analysis for Option of Increasing Ceiling Insulation from R-19 to R-30}

The level of ceiling insulation is increased from R-19 to R-30, changing the total effective ceiling $R$ value from $R-24$ to $R-35$. This is accomplished most economically by adding 3-1/2 in. of fiberglass insulation (which costs $14 \mathrm{C} / \mathrm{ft}^{2}$ ) to the attic. This $\$ 113$ option reduces heating loads by 1.94 million Btu (5\%) and cooling loads by 0.04 million Btu $(0.1 \%)$.

\begin{tabular}{|c|c|c|c|c|c|c|c|c|}
\hline \\
\hline 8 & Year & $\begin{array}{c}\text { Added } \\
\text { Mortgage } \\
\text { Payment } \\
(\$ / y r)\end{array}$ & $\begin{array}{c}\text { Annual } \\
\text { Electric } \\
\text { Cost } \\
\text { Savings } \\
(\$ / y r)\end{array}$ & $\begin{array}{c}\text { Added } \\
\text { Property } \\
\text { Taxes } \\
(\$ / y r) \\
\end{array}$ & $\begin{array}{c}\text { Interest } \\
\text { Tax } \\
\text { Deductions } \\
(\mathbf{S} / \mathrm{yr}) \\
\end{array}$ & $\begin{array}{c}\text { Net } \\
\text { Annual } \\
\text { Savings } \\
(\$ / y r)\end{array}$ & $\begin{array}{c}\text { Net } \\
\text { Annual } \\
\text { Savings } \\
\text { (1980 \$) }\end{array}$ & $\begin{array}{c}\text { Net } \\
\text { Cumulative } \\
\text { Savings } \\
(1980 \text { \$) }\end{array}$ \\
\hline & 0 & -22.60 & 0 & 0 & 0 & -22.60 & -22.60 & -22.60 \\
\hline & 1 & -12.43 & 8.84 & -2.37 & 3.05 & -2.91 & -2.65 & -25.74 \\
\hline & 2 & -12.43 & 10.17 & -2.37 & 3.03 & -1.60 & -1.32 & -26.57 \\
\hline & 3 & -12.43 & 11.70 & -2.37 & 3.03 & -0.07 & -0.05 & -26.62 \\
\hline & 4 & -12.43 & 13.45 & -2.37 & 3.01 & 1.66 & 1.13 & -25.49 \\
\hline & 5 & -12.43 & 15.47 & -2.37 & 3.00 & 3.67 & 2.28 & -23.21 \\
\hline & 6 & -12.43 & 17.79 & -2.37 & 2.97 & 5.96 & 3.36 & -19.85 \\
\hline & 7 & -12.43 & 20.46 & -2.37 & 2.96 & 8.62 & 4.42 & -15.43 \\
\hline & 8 & -12.43 & 23.52 & -2.37 & 2.94 & 11.66 & 5.44 & -9.99 \\
\hline & 9 & -12.43 & 27.05 & -2.37 & 2.91 & 15.16 & 6.43 & -3.56 \\
\hline & 10 & -12.43 & 31.11 & -2.37 & 2.88 & 19.19 & 7.40 & 3.84 \\
\hline
\end{tabular}

Electricity consumption is reduced by $575 \mathrm{kWh}$ and the cash flow breakeven period is just under 10 years.

.

\begin{tabular}{|c|c|c|c|c|c|c|c|c|}
\hline \multirow[b]{2}{*}{ Year } & \multicolumn{7}{|c|}{ Cash Flow for a Home with a Gas Furnace } & \multirow[b]{2}{*}{$\begin{array}{c}\text { Net } \\
\text { Cumulative } \\
\text { Savings } \\
(1980 \$) \\
\end{array}$} \\
\hline & $\begin{array}{c}\text { Added } \\
\text { Mortgage } \\
\text { Payment } \\
(\$ / y r) \\
\end{array}$ & $\begin{array}{c}\text { Annual } \\
\text { Electric } \\
\text { Cost } \\
\text { Savings } \\
(\$ / y r)\end{array}$ & $\begin{array}{c}\text { Natural } \\
\text { Gas } \\
\text { Savings } \\
(\mathbf{\$} / \mathrm{yr}) \\
\end{array}$ & $\begin{array}{c}\text { Added } \\
\text { Property } \\
\text { Taxes } \\
(\mathbf{\$} / \mathrm{yr}) \\
\end{array}$ & $\begin{array}{c}\text { Interest } \\
\text { Tax } \\
\text { Deductions } \\
(\$ / y r) \\
\end{array}$ & $\begin{array}{c}\text { Net } \\
\text { Annual } \\
\text { Savings } \\
(\$ / y r)\end{array}$ & $\begin{array}{c}\text { Net } \\
\text { Annual } \\
\text { Savings } \\
(1980 \$)\end{array}$ & \\
\hline 0 & -22.60 & & & 0 & 0 & -22.60 & -22.60 & -22.60 \\
\hline 1 & -12.43 & 0.08 & 15.24 & -2.37 & 3.05 & 3.57 & 3.25 & -19.35 \\
\hline 2 & -12.43 & 0.09 & 17.98 & -2.37 & 3.03 & 6.30 & 5.21 & -14.14 \\
\hline 3 & -12.43 & 0.11 & 21.22 & -2.37 & 3.03 & 9.56 & 7.18 & -6.96 \\
\hline 4 & -12.43 & 0.12 & 25.04 & -2.37 & 3.01 & 13.37 & 9.13 & 2.17 \\
\hline 5 & -12.43 & 0.14 & 28.55 & -2.37 & 3.00 & 17.89 & 11.11 & 13.28 \\
\hline 6 & -12.43 & 0.16 & 34.87 & -2.37 & 2.97 & 23.20 & 13.10 & 26.38 \\
\hline
\end{tabular}

Natural gas consumption is reduced by 26 therms and electricity by $7 \mathrm{kWh} /$ year. The cash flow breakeven period is just under 4 years. 


\section{Cash Flow Analysis for a Home with a Heat Pump}

Since the heat pump is more efficient than an electric furnace, savings will be smaller. Thus, the economics are less favorable than in the electric furnace case.

\section{B.3.4 Analysis for Option of Increasing Ceiling Insulation From R-30 to R-38}

As the level of ceiling insulation is increased from $R-30$ to $R-38$, the effective ceiling $R$ value changes from R-35 to R-43. This costs about $11 \mathrm{c} / \mathrm{ft}^{2}$ more for materials and installation than does $\mathrm{R}-30$ insulation. For a total additional cost of $\$ 73.00$ this option reduces heating loads by 0.79 million Btu and cooling loads by 0.01 million Btu.

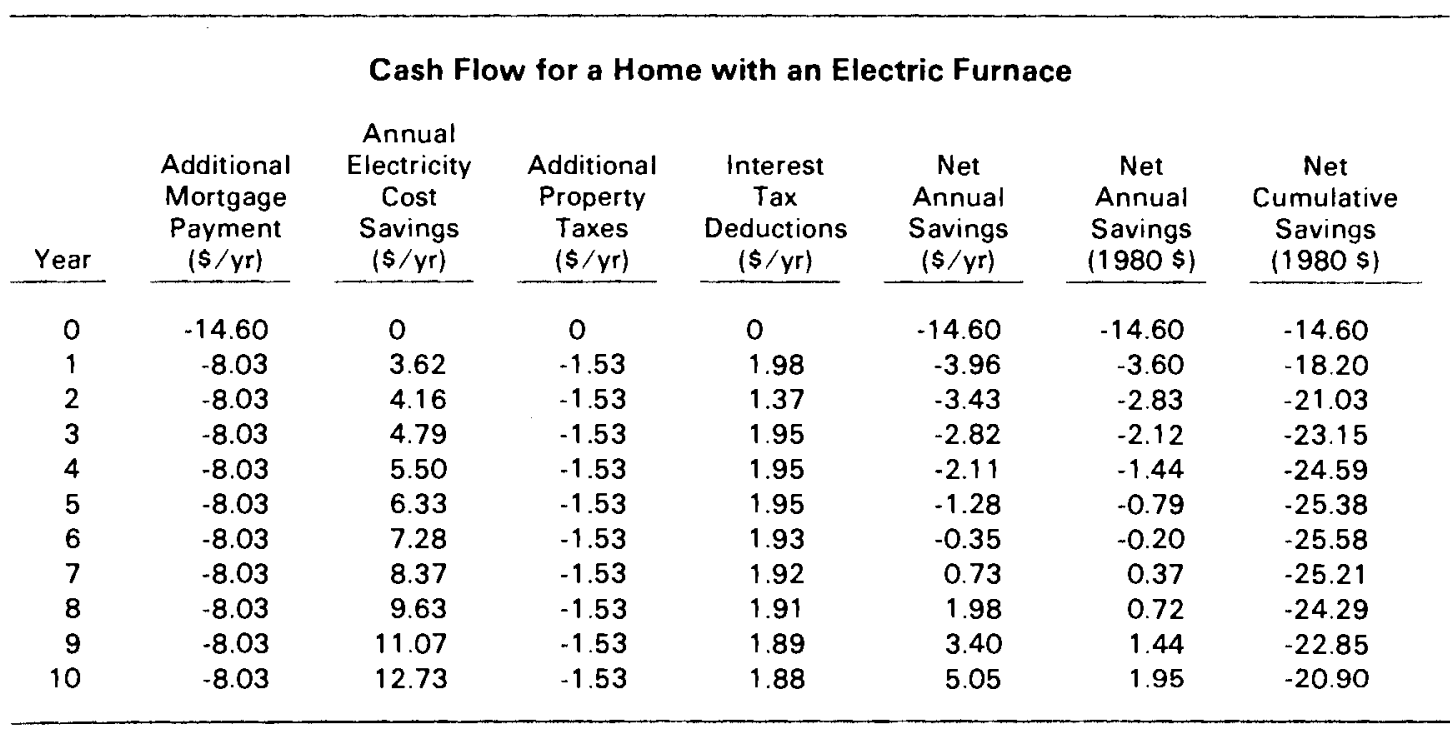

Electricity consumption is only reduced by $234 \mathrm{kWh}$ and the breakeven period is greater than 10 years.

\begin{tabular}{|c|c|c|c|c|c|c|c|c|}
\hline \multirow[b]{2}{*}{ Year } & \multicolumn{8}{|c|}{ Cash Flow for a Home with a Gas Furnace } \\
\hline & $\begin{array}{c}\text { Additional } \\
\text { Mortgage } \\
\text { Payment } \\
(\$ / y r)\end{array}$ & $\begin{array}{c}\text { Electricity } \\
\text { Cost } \\
\text { Savings } \\
\text { (\$/yr) }\end{array}$ & $\begin{array}{c}\text { Natural } \\
\text { Gas } \\
\text { Cost } \\
\text { Savings } \\
(\$ / y r)\end{array}$ & $\begin{array}{c}\text { Additional } \\
\text { Property } \\
\text { Taxes } \\
(\$ / y r)\end{array}$ & $\begin{array}{c}\text { Interest } \\
\text { Tax } \\
\text { Deductions } \\
(\$ / y r)\end{array}$ & $\begin{array}{c}\text { Net } \\
\text { Annual } \\
\text { Savings } \\
(\$ / y r)\end{array}$ & $\begin{array}{c}\text { Net } \\
\text { Annual } \\
\text { Savings } \\
\text { (1980 s) }\end{array}$ & $\begin{array}{c}\text { Net } \\
\text { Cumulative } \\
\text { Savings } \\
(1980 \text { \$) }\end{array}$ \\
\hline 0 & 14.60 & 0 & 0 & 0 & 0 & -14.60 & -14.60 & -14.60 \\
\hline 1 & -8.03 & 0.02 & 6.21 & -1.53 & 1.98 & -1.35 & -1.23 & -15.83 \\
\hline 2 & -8.03 & 0.02 & 7.33 & -1.53 & 1.97 & -0.24 & -0.20 & -16.03 \\
\hline 4 & -8.03 & 0.03 & 10.20 & -1.53 & 1.95 & 2.62 & 1.79 & -13.44 \\
\hline 5 & -8.03 & 0.03 & 12.04 & -1.53 & 1.95 & 4.46 & 2.77 & -10.67 \\
\hline 6 & -8.03 & 0.04 & 14.21 & -1.53 & 1.93 & 6.62 & 3.74 & -6.93 \\
\hline 7 & -8.03 & 0.04 & 16.76 & -1.53 & 1.92 & 9.16 & 4.70 & -2.23 \\
\hline 8 & -8.03 & 0.05 & 19.98 & -1.53 & 1.91 & 12.18 & 5.68 & 3.45 \\
\hline 9 & -8.03 & 0.06 & 23.34 & -1.53 & 1.89 & 15.78 & 6.69 & 10.14 \\
\hline 10 & -8.03 & 0.07 & 27.54 & -1.53 & 1.88 & 19.93 & 7.68 & 17.82 \\
\hline
\end{tabular}


Electricity consumption is reduced by $3 \mathrm{kWh}$ and natural gas consumption by 11.3 therms. The breakeven period is 8 years.

\section{Cash Flow Analysis for a Home with a Heat Pump}

Since the heat pump uses less energy than an electric furnace, less energy is conserved by the added insulation and the breakeven period is greater than 10 years.

\section{B.3.5 Analysis for Option of Replacing Double Glazing with Triple Glazing}

- Increasing window glazing from double pane to triple pane increases the R-value of the

1 window from R-1.9 to R-3.1, but reduces solar transmittance from $75 \%$ to $65 \%$ of incident radiation. In addition, triple glazing reduces infiltration and improves the thermal performance of the window frame. A cost of $\$ 1.81 / \mathrm{ft}^{2}$ for the glazing was estimated for a total option cost of $\$ 311$. Heating loads were reduced by 9.7 million Btu (27\%) and cooling loads by 1.0 million Btu (15\%).

\begin{tabular}{|c|c|c|c|c|c|c|c|}
\hline \multirow[b]{2}{*}{ Year } & \multicolumn{6}{|c|}{ Cash Flow for a Home with an Electric Furnace } & \multirow[b]{2}{*}{$\begin{array}{c}\text { Net } \\
\text { Cumulativ } \\
\text { Savings } \\
(1980 \$) \\
\end{array}$} \\
\hline & $\begin{array}{c}\text { Additional } \\
\text { Mortgage } \\
\text { Payment } \\
\text { (\$/yr) }\end{array}$ & $\begin{array}{c}\text { Annual } \\
\text { Electricity } \\
\text { Cost } \\
\text { Savings } \\
(\$ / y r)\end{array}$ & $\begin{array}{c}\text { Additional } \\
\text { Property } \\
\text { Taxes } \\
(\$ / y r) \\
\end{array}$ & $\begin{array}{c}\text { Interest } \\
\text { Tax } \\
\text { Deductions } \\
(\$ / y r)\end{array}$ & $\begin{array}{c}\text { Net } \\
\text { Annual } \\
\text { Savings } \\
(\$ / y r)\end{array}$ & $\begin{array}{c}\text { Net } \\
\text { Annual } \\
\text { Savings } \\
\text { (1980 \$) }\end{array}$ & \\
\hline 0 & -62.20 & 0 & 0 & 0 & -62.20 & -62.20 & -62.20 \\
\hline 1 & -34.20 & 46.15 & -6.53 & 8.39 & 13.81 & 12.55 & -49.65 \\
\hline 2 & -34.20 & 53.08 & -6.53 & 8.37 & 20.72 & 17.12 & -32.53 \\
\hline 3 & -34.20 & 61.04 & -6.53 & 8.34 & 28.65 & 21.53 & -11.00 \\
\hline 4 & -34.20 & 70.19 & -6.53 & 8.31 & 37.77 & 25.80 & 14.80 \\
\hline 5 & 34.20 & 80.72 & -6.53 & 8.27 & 48.26 & 29.97 & 44.77 \\
\hline 6 & -34.20 & 92.83 & -6.53 & 8.24 & 60.34 & 34.06 & 78.83 \\
\hline
\end{tabular}

This option results in saving $2997 \mathrm{kWh}$ and reaches the breakeven point during the fourth year.

Cash Flow for a Home with Gas Heat

\begin{tabular}{|c|c|c|c|c|c|c|c|c|c|}
\hline$\therefore$ & Year & $\begin{array}{c}\text { Additional } \\
\text { Mortgage } \\
\text { Payment } \\
(\$ / Y r)\end{array}$ & $\begin{array}{c}\text { Electricity } \\
\text { Cost } \\
\text { Savings } \\
(\$ / y r)\end{array}$ & $\begin{array}{c}\text { Natural } \\
\text { Gas } \\
\text { Cost } \\
\text { Savings } \\
(\$ / y r)\end{array}$ & $\begin{array}{l}\text { Additional } \\
\text { Property } \\
\text { Taxes } \\
(\$ / y r)\end{array}$ & $\begin{array}{c}\text { Interest } \\
\text { Tax } \\
\text { Deductions } \\
(\$ / y r)\end{array}$ & $\begin{array}{c}\text { Net } \\
\text { Annual } \\
\text { Savings } \\
(\$ / y r)\end{array}$ & $\begin{array}{c}\text { Net } \\
\text { Annual } \\
\text { Savings } \\
\text { (1980 \$) }\end{array}$ & $\begin{array}{c}\text { Net } \\
\text { Cumulative } \\
\text { Savings } \\
\text { (1980 \$) }\end{array}$ \\
\hline- & 0 & -62.20 & 0 & 0 & 0 & 0 & .62 .20 & -62.20 & -60.20 \\
\hline . & 1 & -34.20 & 1.88 & 78.10 & -6.53 & 8.39 & 47.64 & 43.31 & -18.89 \\
\hline & 2 & -34.20 & 2.16 & 92.16 & -6.53 & 8.37 & 61.76 & 51.21 & 32.32 \\
\hline & 3 & -34.20 & 2.49 & 108.75 & -6.53 & 8.34 & 78.85 & 59.24 & 91.56 \\
\hline & 4 & -34.20 & 2.86 & 128.32 & -6.53 & 8.31 & 98.76 & 67.45 & 159.01 \\
\hline
\end{tabular}


Annual savings of $122 \mathrm{kWh}$ of electricity and 142 therms of gas would result from installation of this option. The breakeven point occurs in the second year.

\begin{tabular}{|c|c|c|c|c|c|c|c|}
\hline \multirow[b]{2}{*}{ Year } & \multicolumn{7}{|c|}{ Cash Flow for a Home with a Heat Pump } \\
\hline & $\begin{array}{c}\text { Added } \\
\text { Mortgage } \\
\text { Payment } \\
(\$ / y r) \\
\end{array}$ & $\begin{array}{c}\text { Annual } \\
\text { Electric } \\
\text { Cost } \\
\text { Savings } \\
(\$ / y r)\end{array}$ & $\begin{array}{c}\text { Added } \\
\text { Property } \\
\text { Taxes } \\
(\$ / y r) \\
\end{array}$ & $\begin{array}{c}\text { Interest } \\
\text { Tax } \\
\text { Deductions } \\
(\$ / y r) \\
\end{array}$ & $\begin{array}{c}\text { Net } \\
\text { Annual } \\
\text { Savings } \\
(\$ / y r)\end{array}$ & $\begin{array}{c}\text { Net } \\
\text { Annual } \\
\text { Savings } \\
\text { (1980 \$) }\end{array}$ & $\begin{array}{c}\text { Net } \\
\text { Cumulative } \\
\text { Savings } \\
(1980 \$) \\
\end{array}$ \\
\hline 0 & -62.00 & 0 & 0 & 0 & -62.00 & -62.00 & -62.00 \\
\hline 1 & -34.09 & 27.15 & -6.51 & 8.36 & 4.73 & -4.30 & -66.30 \\
\hline 2 & .34 .09 & 31.22 & -6.51 & 8.34 & -1.04 & -0.86 & -67.16 \\
\hline 3 & -34.09 & 35.90 & -6.51 & 8.31 & 3.61 & 2.71 & -64.45 \\
\hline 4 & -34.09 & 41.29 & -6.51 & 8.28 & 8.97 & 6.13 & -58.32 \\
\hline 5 & -34.09 & 47.48 & -6.51 & 8.25 & 15.13 & 9.39 & -48.93 \\
\hline 6 & .34 .09 & 54.60 & -6.51 & 8.21 & 22.21 & 12.54 & -36.39 \\
\hline 7 & -34.09 & 62.79 & -6.51 & 8.17 & 30.36 & 15.58 & -20.81 \\
\hline 8 & -34.09 & 72.21 & -6.51 & 8.11 & 39.72 & 18.53 & -2.28 \\
\hline 9 & -34.09 & 83.04 & -6.51 & 8.05 & 50.49 & 21.41 & 19.13 \\
\hline 10 & -34.09 & 95.50 & -6.51 & 7.99 & 62.89 & 24.25 & 43.38 \\
\hline
\end{tabular}

The breakeven point is reached in 9 years. Electricity consumption is decreased by $1763 \mathrm{kWh}$ annually.

\section{B.3.6 Analysis for Option of Installing a Storm Door}

A glass pane storm door is installed over an insulated door, increasing the R-value from R-13 to $R-16$ and reducing infiltration by $10 \%$. The feature is estimated to cost $\$ 120.00$ and reduces heating loads by 2.3 million Btu (6\%) and cooling loads by 0.3 million Btu (43\%). Installing a storm door over a wood door results in about $25 \%$ greater savings since a wood door has an R-value of only 1.5 .

Cash Flow for a Home with Electric Heat

\begin{tabular}{|c|c|c|c|c|c|c|c|}
\hline Year & $\begin{array}{c}\text { Added } \\
\text { Mortgage } \\
\text { Payment } \\
(\$ / y r) \\
\end{array}$ & $\begin{array}{c}\text { Annual } \\
\text { Electric } \\
\text { Cost } \\
\text { Savings } \\
(\$ / y r)\end{array}$ & $\begin{array}{c}\text { Added } \\
\text { Property } \\
\text { Taxes } \\
(\$ / y r) \\
\end{array}$ & $\begin{array}{c}\text { Interest } \\
\text { Tax } \\
\text { Deductions } \\
\text { (\$/yr) }\end{array}$ & $\begin{array}{c}\text { Net } \\
\text { Annual } \\
\text { Savings } \\
(\$ / y r)\end{array}$ & $\begin{array}{c}\text { Net } \\
\text { Annual } \\
\text { Savings } \\
(1980 \text { \$) }\end{array}$ & $\begin{array}{c}\text { Net } \\
\text { Cumulative } \\
\text { Savings } \\
(1980 \text { \$ }) \\
\end{array}$ \\
\hline 0 & -24.00 & 0 & 0 & 0 & -24.00 & -24.00 & -24.00 \\
\hline 1 & -13.20 & 11.06 & -2.52 & 3.24 & -1.42 & -1.29 & -25.29 \\
\hline 2 & -13.20 & 12.72 & -2.52 & 3.24 & 0.24 & 0.20 & -25.09 \\
\hline 3 & -13.20 & 14.63 & -2.52 & 3.21 & 2.12 & 1.59 & -23.50 \\
\hline 4 & -13.20 & 16.83 & -2.52 & 3.21 & 4.32 & 2.95 & -20.55 \\
\hline 5 & -13.20 & 19.34 & -2.52 & 3.19 & 6.81 & 4.23 & -16.32 \\
\hline 6 & -13.20 & 22.25 & -2.52 & 3.18 & 9.71 & 5.48 & -10.84 \\
\hline 7 & -13.20 & 25.58 & -2.52 & 3.16 & 13.02 & 6.68 & -4.16 \\
\hline 8 & -13.20 & 29.42 & -2.52 & 3.14 & 16.84 & 7.86 & 3.70 \\
\hline 9 & -13.20 & 33.83 & -2.52 & 3.12 & 21.23 & 9.00 & 12.70 \\
\hline 10 & -13.20 & 38.91 & -2.52 & 3.09 & 27.28 & 10.52 & 23.22 \\
\hline
\end{tabular}


Electricity savings are $718 \mathrm{kWh}$ annually. The breakeven point is reached after the seventh year.

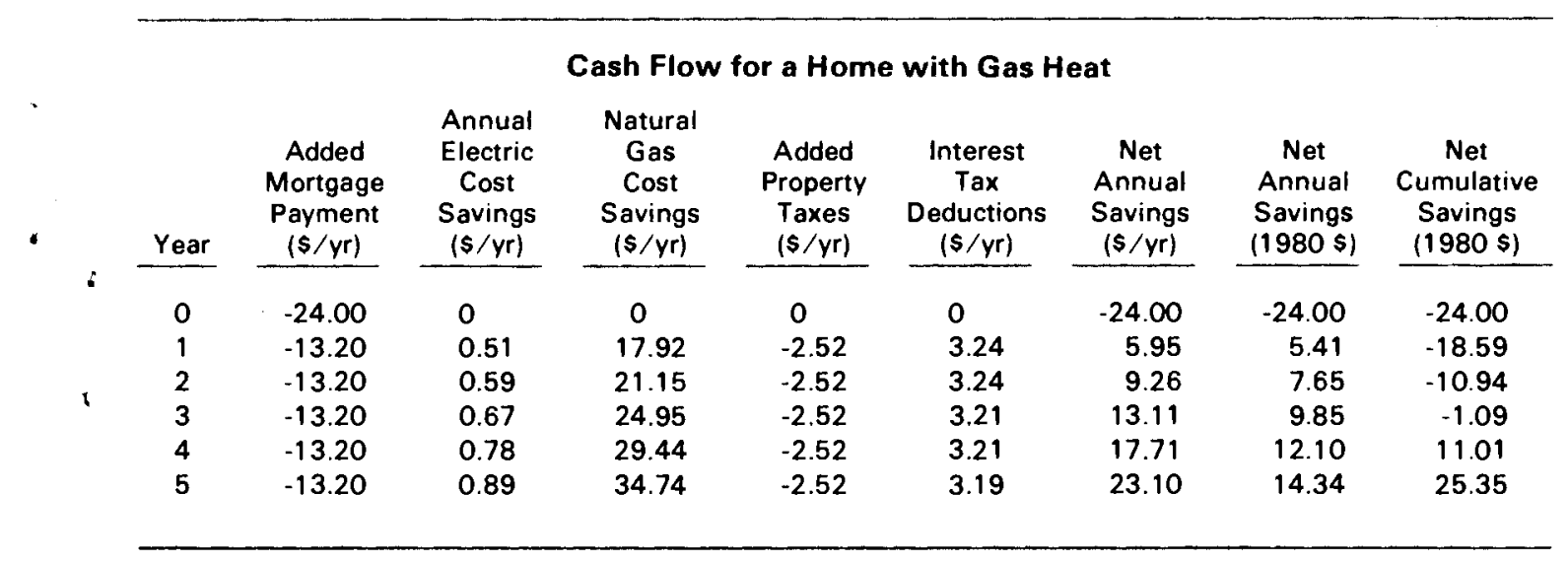

Electricity consumption decreases by $33 \mathrm{kWh}$ and gas by 33 therms. This results in a breakeven point in the cash flow after 3 years.

\section{Cash Flow for a Home with a Heat Pump}

While an energy savings of $423 \mathrm{kWh}$ is realized, the period required to breakeven is greater than 10 years.

\section{B.3.7 Analysis for Option of a Night Setback Thermostat}

- This analysis is based on installation of an automatic night setback thermostat, which is programmed to reduce the temperature to $55^{\circ} \mathrm{F}$ between the hours of midnight and 7:00 a.m. . The device is assumed to cost $\$ 40.00$ and reduces heating loads by 4.2 million Btu $(11 \%)$.

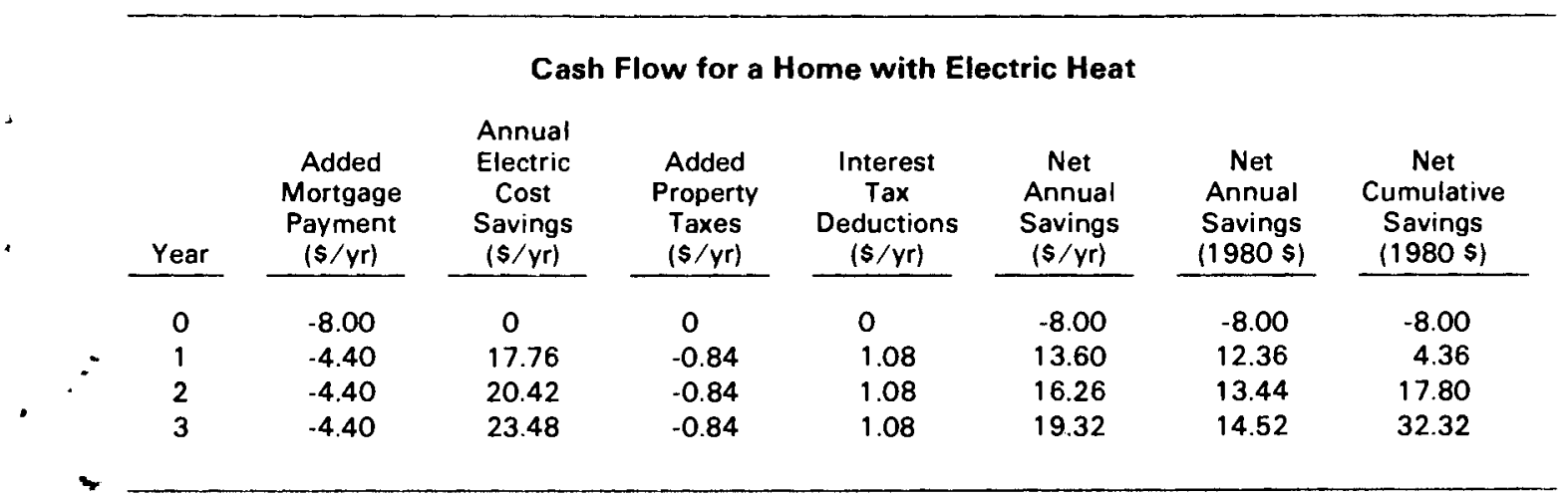

- Annual electricity savings are $1153 \mathrm{kWh}$. The breakeven point occurs during the first year. 


\section{Cash Flow for a Home with Gas Heat}

\begin{tabular}{|c|c|c|c|c|c|c|c|c|}
\hline Year & $\begin{array}{c}\text { Added } \\
\text { Mortgage } \\
\text { Payment } \\
(\mathrm{S} / \mathrm{yr})\end{array}$ & $\begin{array}{c}\text { Annual } \\
\text { Electric } \\
\text { Cost } \\
\text { Savings } \\
(\$ / y r) \\
\end{array}$ & $\begin{array}{c}\text { Natural } \\
\text { Gas } \\
\text { Cost } \\
\text { Savings } \\
(\$ / y r) \\
\end{array}$ & $\begin{array}{c}\text { Added } \\
\text { Property } \\
\text { Taxes } \\
(\$ / y r) \\
\end{array}$ & $\begin{array}{c}\text { Interest } \\
\text { Tax } \\
\text { Deductions } \\
(\mathbf{S} / \mathrm{yr}) \\
\end{array}$ & $\begin{array}{c}\text { Net } \\
\text { Annual } \\
\text { Savings } \\
\text { (s/yr) }\end{array}$ & $\begin{array}{c}\text { Net } \\
\text { Annual } \\
\text { Savings } \\
(1980 \text { \$) }\end{array}$ & $\begin{array}{c}\text { Net } \\
\text { Cumulative } \\
\text { Savings } \\
\text { (1980 \$) }\end{array}$ \\
\hline 0 & -8.00 & 0 & 0 & 0 & 0 & -8.00 & -8.00 & -8.00 \\
\hline 1 & -4.40 & 0 & 30.93 & -084 & 1.08 & 26.77 & 24.34 & 16.34 \\
\hline 2 & -4.40 & 0 & 36.50 & -0.84 & 1.08 & 32.34 & 26.73 & 43.07 \\
\hline 3 & -4.40 & 0 & 43.07 & -0.84 & 1.08 & 38.91 & 29.23 & 72.30 \\
\hline
\end{tabular}

An annual savings of 56 therms results and the breakeven point is reached during the first year.

\begin{tabular}{|c|c|c|c|c|c|c|c|}
\hline \multirow[b]{2}{*}{ Year } & \multicolumn{6}{|c|}{ Cash Flow for a Home with a Heat Pump } & \multirow[b]{2}{*}{$\begin{array}{c}\text { Net } \\
\text { Cumulative } \\
\text { Savings } \\
(1980 \text { \$) }\end{array}$} \\
\hline & $\begin{array}{c}\text { Added } \\
\text { Mortgage } \\
\text { Payment } \\
(\$ / y r)\end{array}$ & $\begin{array}{c}\text { Annual } \\
\text { Electric } \\
\text { Cost } \\
\text { Savings } \\
(\$ / y r)\end{array}$ & $\begin{array}{l}\text { Added } \\
\text { Property } \\
\text { Taxes } \\
(s / y r)\end{array}$ & $\begin{array}{c}\text { Interest } \\
\text { Tax } \\
\text { Deductions } \\
(\$ / y r)\end{array}$ & $\begin{array}{c}\text { Net } \\
\text { Annual } \\
\text { Savings } \\
(\$ / y r)\end{array}$ & $\begin{array}{c}\text { Net } \\
\text { Annual } \\
\text { Savings } \\
(1980 \$)\end{array}$ & \\
\hline 0 & -8.00 & 0 & 0 & 0 & -8.00 & -8.00 & -8.00 \\
\hline 1 & -4.40 & 10.45 & -0.84 & 1.08 & 6.29 & 5.72 & -2.28 \\
\hline 2 & -4.40 & 12.01 & -0.84 & 1.08 & 7.85 & 6.49 & 4.21 \\
\hline 3 & -4.40 & 13.82 & -0.84 & 1.08 & 9.66 & 7.26 & 11.47 \\
\hline 4 & -4.40 & 15.89 & -0.84 & 1.07 & 11.72 & 8.00 & 19.47 \\
\hline
\end{tabular}

The annual electricity savings with this option is $679 \mathrm{kWh}$ and the breakeven point occurs in the second year.

\section{B.3.8 Analysis for Option of a Flue Damper}

The installation of a good quality flue damper costs about $\$ 180.00$ and increases the efficiency of the natural gas furnace from $70 \%$ to $80 \%$. This reduces natural gas consumption by 54 therms annually. The breakeven point occurs in the third year.

\begin{tabular}{|c|c|c|c|c|c|c|c|c|}
\hline Year & $\begin{array}{c}\text { Added } \\
\text { Mortgage } \\
\text { Payment } \\
(\$ / y r) \\
\end{array}$ & $\begin{array}{c}\text { Annual } \\
\text { Electric } \\
\text { Cost } \\
\text { Savings } \\
(\mathbf{S} / \mathrm{yr}) \\
\end{array}$ & $\begin{array}{c}\text { Natural } \\
\text { Gas } \\
\text { Cost } \\
\text { Savings } \\
(\$ / y r) \\
\end{array}$ & $\begin{array}{c}\text { Added } \\
\text { Property } \\
\text { Taxes } \\
(\$ / y r) \\
\end{array}$ & $\begin{array}{c}\text { Interest } \\
\text { Tax } \\
\text { Deductions } \\
(\$ / y r) \\
\end{array}$ & $\begin{array}{c}\text { Net } \\
\text { Annual } \\
\text { Savings } \\
(\$ / y r) \\
\end{array}$ & $\begin{array}{c}\text { Net } \\
\text { Annua! } \\
\text { Savings } \\
(1980 \$) \\
\end{array}$ & $\begin{array}{c}\text { Net } \\
\text { Cumulative } \\
\text { Savings } \\
(1980 \$) \\
\end{array}$ \\
\hline 0 & -36.00 & 0 & 0 & 0 & 0 & -36.00 & -36.00 & -36.00 \\
\hline 1 & -19.79 & 0 & 29.50 & -3.78 & 4.86 & 10.79 & 9.81 & -26.19 \\
\hline 2 & -19.79 & 0 & 34.81 & -3.78 & 4.84 & 16.08 & 13.29 & -12.90 \\
\hline 3 & -19.79 & 0 & 41.08 & -3.78 & 4.83 & 22.34 & 16.78 & 3.88 \\
\hline 4 & -19.79 & 0 & 48.47 & -3.73 & 4.81 & 29.71 & 20.29 & 24.17 \\
\hline 5 & -19.79 & 0 & 57.19 & -3.78 & 4.79 & 38.41 & 23.85 & 48.02 \\
\hline
\end{tabular}




\section{Analysis of Water Heating Options}

Calculation of the energy cost savings from a particular water-saving device requires knowledge of the amount of water (G) saved by the device, the temperature (T) of the water saved, and the price of the fuel used to heat the water. To demonstrate this calculation, the savings for a shower flow restrictor in a home in Hermiston, Oregon, are shown here.

An average shower-head provides water at a rate of 5 to $15 \mathrm{gal} / \mathrm{min}$. By installing a shower flow restrictor, this can be reduced to 2 to $4 \mathrm{gal} / \mathrm{min}$, for a savings of 1 to $13 \mathrm{gal} / \mathrm{min}$. If a conservative estimate of the water savings $(2.5 \mathrm{gal} / \mathrm{min})$ is used and household members take 4-minute showers, then the savings per shower is $10 \mathrm{gal}$. If the household consists of four people who take five showers/week, then the household will save 10,400 gal/year or:

4 people $\times 10 \mathrm{gal} /$ shower $\times 5$ showers $/$ week $\times 52$ weeks $/$ year $=10,400 \mathrm{gal}$

If the water enters the house at $55^{\circ} \mathrm{F}$ (average ground temperature) and is used at $107^{\circ} \mathrm{F}$ in the shower, the energy content of the water that is saved can be calculated as:

$$
\begin{aligned}
& \text { Energy }=\left(T-55^{\circ}\right) \times 8.34 \times \mathrm{G} \\
& \text { Energy }=(107-55) \times 8.34 \times 10,400=4.5 \times 10^{6} \mathrm{Btu}
\end{aligned}
$$

The value of 8.34 is required (because water weights $8.34 \mathrm{lb} /$ gal) to calculate energy in Btu. Since $1 \mathrm{kWh}$ is equivalent to $3413 \mathrm{Btu}, 4.5 \times 10^{6} \mathrm{Btu}$ is equivalent to $1320 \mathrm{kWh}$.(a) The monetary savings due to the shower flow restrictor can be calculated from $1320 \mathrm{kWh} \times$ the price of electricity in $\$ / \mathrm{kWh}$. In Hermiston, the Umatilla Public Utility currently sells electricity for $1.54 \mathrm{c} / \mathrm{kWh}$. Thus, the annual expected savings to a family of four with an electric hot water heater resulting from installation of a shower flow restrictor is $\$ 20.33 /$ year. At a cost of less than $\$ 5.00$ the shower flow restrictor would pay for itself in less than one year and these monetary savings would increase over time as the price of electricity rises.

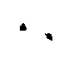

(a) The energy content of the water saved is equal to the actual energy saved because heat transfer in electric hot water heaters is essentially $100 \%$ efficient. In gas or oil water heaters, the energy content of the water must be divided by the efficiency of the water heater (usually between 0.5 and 0.7 ) to convert energy content to energy savings. 


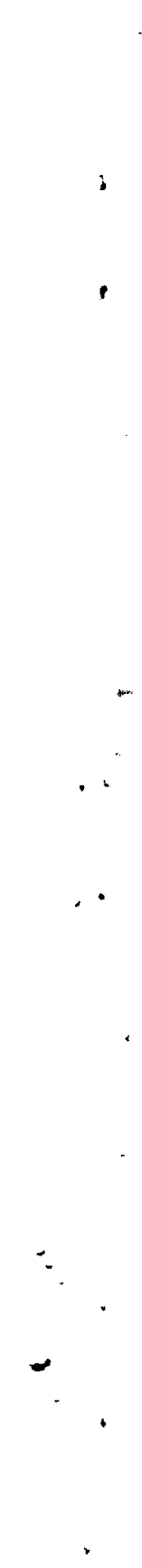




\section{References}

Briggs, J. B. and C. J. Shaffer. 1977. Seasonal Heat Pump Performance for Typical Northern U.S. Environments. TREE 1181, EG\&G, Idaho Falls, Idaho. 


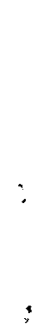

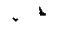

,

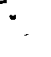

..

- 


\section{Distribution}

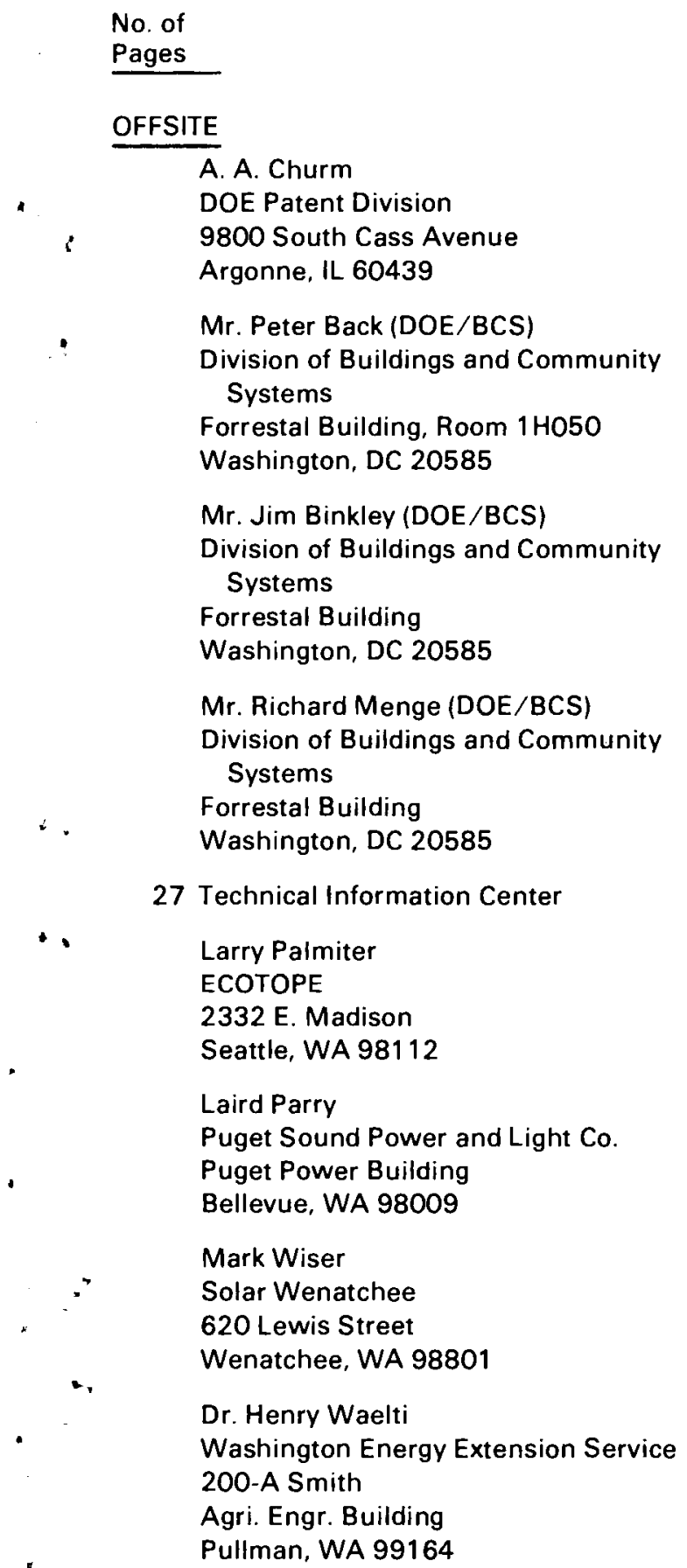

No. of

Pages

Washington State Energy Office Energy Library 400 E. Union Street Olympia, Washington 98504

Jay Luboff

Western SUN Washington Office FS 15

University of Washington

Seattle, WA 98195

John Shaw

Yakima solar Energy Association 8001 Englewood Crest Drive

Yakima, Wa 98908

Rick Reil

Benton County PUD

524 S. Auburn Street

P.O. Box 6270

Kennewick, WA 99336

Energy Auditor

Benton Rural Electric Association 402 7th Street

P.O. Box 150

Prosser, WA 99350

David Jack

City of Ellensburg

420 N. Pearl Street

Ellensburg, WA 98926

Joan Swanson

Franklin County PUD

1411 W. Clark Street

Pasco, WA 99302

Energy Auditor

Kittitas County PUD

301 N. Main Street

Box 218

Ellensburg, WA 98926 
Energy Auditor

City of Richland

Energy Services Department

P.O. Box 190

Richland, WA 99352

Energy Audit Department

Seattle City Light

1015 Third Avenue

Seattle, WA 98104

Don Davey

Bonneville Power Administration

P.O. Box 3621

Portland, OR 97208

Marion Hemphill

City Energy Advisor

City of Portland

1220 S.W. 5th Avenue

Portland, OR 97205

5 Stan Gass

S. H. Gass Construction Company 1050 North First Street

Hermiston, OR 97838

David Werner

Energy Consultant

Pacific Power Co.

705 S. First Street

Hermiston, OR 97838

Mr. Harry Misuriello

W. S. Fleming \& Associates, Inc

Two Metro Plaza, Suite 204

8240 Professional Place

Landover, MD 20785
Mr. Michael Gilford

Gilford, Deringer \& Company

117 th St. N.E.

Washington, DC 20002

Mr. Joseph Deringer

Gilford, Deringer \& Company

1117 th St. N.E.

Washington, DC 20002

Mr. Mark Levine

Lawrence Berkeley Laboratories

1 Cyclotron Road, Bldg. 90.

Room 3114

Berkeley, CA 94720

ONSITE

DOE Richland Operations Office

H. E. Ransom

192 Pacific Northwest Laboratory

C. H. Bloomster

T. J. Foley (99) :

W. J. Hopp (5)

R. P. Mazzucchi (50)

L. A. Nieves (10)

L. D. Williams (5),

L. Wilheilmi (15),

Technical Information (5)

Publishing Coordination KE(2) 